\title{
Mobile payments: a proposal for a context-oriented approach based on socio-technical system theory
}

\author{
Tatjana Apanasevic \\ tatjanaa@kth.se|Department of Communication Systems, KTH Royal Institute of Technology, Kista, \\ Sweden \\ Niklas Arvidsson \\ niklas.arvidsson@indek.kth.se | Department of Industrial Dynamics, KTH Royal Institute of \\ Technology, Stockholm, Sweden \\ Jan Markendahl \\ janmar@kth.se| Department of Communication Systems, KTH Royal Institute of Technology, Kista, \\ Sweden
}

\begin{abstract}
A recent review of mobile payment research by Dahlberg et al. (2015) concludes that there is a need to synthesise this research area by studying contexts in which innovation is carried out and to integrate different aspects of research. This article aims to provide a proposal for how to achieve such integration and context orientation by building on previous studies and offering an additional review. Our systematic literature review of mobile payments research is focused on papers published during 2006-2016. The main objective is to examine how mobile payments research has been conducted from the methodological and theoretical perspectives. Our findings show that research on mobile payments is a multidisciplinary research. Three main themes in the research (in line with previous studies) are customer adoption, technological aspects, and business aspects. Moreover, research is mainly analytical based on a deductive approach. To meet the challenge formulated in the previous research, we propose and apply a socio-technical system framework to achieve synthesis and context-specific consideration in future research on mobile payments.
\end{abstract}

Keywords. Literature review; Mobile payments; m-Payments; Socio-technical systems.

Cite paper as: Apanasevic, T., Arvidsson, N., Markendahl, J., (2018). Mobile payments: a proposal for a context-oriented approach based on socio-technical system theory, Journal of Innovation Management, www.openjim.org, 6(3), 40-97. http://hdl.handle.net/10216/116396 


\section{Introduction}

Research on mobile payments has been carried out for almost two decades. A review of academic research performed during the period 1999-2006 is presented in Dahlberg, Mallat, et al. (2008). The authors contribute to academic research by offering: (i) a proposed definition of mobile payments; (ii) development of a multi-dimensional framework based on Porter's Five Forces and contingency theory, which is applied to analyse the mobile payments market; (iii) identification of research fragmentation and a focus on two aspects of mobile payments: technology and customer adoption; and (iv) a proposal of 22 research directions for further research. This was one of the first literature reviews in the area of mobile payments and laid a foundation for research to come.

In 2015, a new critical review of mobile payments research by Dahlberg et al. (2015) was published. Here, the researchers reviewed papers published in the period 2006-2014. The major contributions by Dahlberg et al. (2015) are: (i) identification of research fragmentation and a focus on three aspects of mobile payments: technology, customer adoption, and mobile payments market and providers; (ii) analysis of recent research in the area in relation to the 22 research directions proposed in Dahlberg, Mallat, et al. (2008); (iii) authorship analysis; and (iv) critical comments and recommendations for further research. Their review made several critical comments on the way research in the area had been done and proposed, among other things, that there is a need to put more focus on the role of the contexts - or ecosystems - in which innovation is done as well to strive to integrate several critical dimensions, such as technology, strategy and adoption, in a coherent framework.

Our paper therefore aims to build a more coherent framework around ecosystems for mobile payments and thereby address some of the recommendations made by Dahlberg et al. (2015). Previous reviews (Dahlberg, Mallat, et al., 2008; Dahlberg et al., 2015) did not, however, have a focus on methodological and theoretical issues and we therefore decided to complement their reviews with our review that incorporates methodologies and theories. The primary objective of our paper is to examine how mobile payment research has been conducted from the methodological and theoretical perspectives, and thereby be able to propose a framework that enables the research community to address current research challenges. Our study will address the following aspects:

1. What are the most common research and methodological approaches?

2. What are the main research themes and research focuses in the mobile payments research?

3. Given our first two questions, we seek to develop a proposal for a research framework to enable the research community to address the system-oriented challenge proposed by Dahlberg et al. (2015).

The main contributions of our study are: (i) it provides a focused study of methodological and theoretical aspects of the mobile payments research in order to identify the evolution of methodological and theoretical approaches used over time and possible future trends; (ii) it offers a comparison of differences and similarities between this research results and the results of literature reviews previously implemented by Dahlberg, Mallat, et al. (2008) and Dahlberg et al., (2015) in order to verify identified trends and issues; and (iii) it presents an application of the analysis and the development of a classification framework. 
In order to perform a systematic literature review, we defined a number of literature search and selection criteria, together with a classification framework. Then we classified the selected academic literature along different conceptual, methodological, theoretical, and contextual dimensions.

The main findings show that the research in the area of mobile payments is rather new and developing. It is possible to identify three dominant research perspectives or themes: customer adoption, business, and technological aspects. Hence, following Morillo et al. (2003), the research on mobile payments can be considered multidisciplinary, since the subject of research is analysed from different angles and using different disciplines without their full integration. In this research, we identified dependence between research, methodological, theoretical approaches and corresponding disciplines. Due to a clear dominance of three major themes, the research on the mobile payments is fragmented, with a range of uncovered aspects. This led us to propose an integrative research framework based on theories for innovation and change in the socio-technical system that may lead the research in this area to become better integrated and context-oriented.

The rest of the paper is structured as follows: the methodology and classification framework are presented in the next section. This is followed by a description of the major research findings. Then we provide a discussion on the research findings, make conclusions based on that and propose an integrative research framework.

\section{Methodology}

\subsection{Prior literature review studies on mobile payments}

One of the most cited papers on mobile payments is the literature review conducted by Dahlberg, Mallat, et al. (2008). This study provides an overview of papers published during the period 1999-2006. In 2013, Slade et al. (2013) performed a review of publications focused on mobile payments adoption. Dennehy and Sammon (2015) analysed the top 20 cited papers published between 1999 and 2014: the estimation of the top cited papers was based upon Google Scholar's ranking. The same year, Dahlberg et al. (2015) published their literature review of mobile payments research covering the period 2007-2014.

More recently, Taylor (2016) examined academic research papers with a focus on potential risks that mobile payments technologies cause in the retail industry. De Albuquerque et al. (2016) implemented a comprehensive review of peer-reviewed publications published between 2001 and 2011. This review included papers on mobile payments initiatives in developed and developing countries. However, wesupport Dahlberg et al.'s (2015, p. 266) argument that "mixing articles focusing on developing and developed markets could cause confusion about the progress of mobile payments research" due to completely different market environments. Consequently, our study focuses specifically on mobile payments research in developed economies. In addition, we excluded the literature surveys discussed above from our literature review since we aimed to build a broad picture of previous research. However, we build on the findings of other reviews when discussing our results. 


\subsection{Literature search}

We used a systematic literature review approach (Kitchenham et al., 2009; Kitchenham and Brereton, 2013) to ensure a methodologically rigorous overview of research results. The aim of this approach is "not just to aggregate all existing evidence on a research question; it is also intended to support the development of evidence-based guidelines for practitioners" (Kitchenham et al., 2009, p. 8). Our review should be seen as a complement to the literature reviews conducted by Dahlberg, Mallat, et al. (2008) and Dahlberg et al. (2015). We set the following conditions for the study:

1. The target period. Dahlberg, Mallat, et al. (2008) covered the period from 1999 to August 2006. The target period of the current research was set from September 2006 to December 2016.

2. The literature search sources. Similar to Dahlberg, Mallat, et al. (2008), the current research is focused on studies conducted in mobile payments that were published in academic journals and in some established conferences dedicated to information systems and electronic commerce. A list of included conferences and a comparison with Dahlberg, Mallat, et al. (2008) and Dahlberg et al. (2015) is provided in Table 1. A similar list of online academic and conference databases was used for a wide systematic literature scan (see Table 2). Books, book chapters, doctoral dissertations, and unpublished publications were excluded.

3. The literature search process. The descriptors "mobile payment", "m-payment", and "wireless payment" were used for the search. The descriptors were to be found in the title, abstract, or keywords of the article. In addition, a backwards search was used when reviewing references used in the articles. Papers were excluded from the research if the main focus of the research was mobile or electronic commerce, mobile services, mobile finance, or mobile banking, and mobile payments were just a minor part of the research. In addition, if it was possible to track that a conference paper had evolved into a journal paper then the conference paper was omitted.

Based on the search descriptors, about 3,260 papers were found. In order to limit the number of articles, we selected papers based on estimated selection criteria: conference papers from established conferences and articles from journals with a one year or five year impact factor higher than 1.0, or articles from journals with a lower impact factor but more than ten Web of Science or Google Scholar citations. This way we selected 145 papers.

Table 1. Conferences included in the literature search.

\begin{tabular}{lccc}
\hline Conferences & $\begin{array}{c}\text { Dahlberg, } \\
\text { Mallat, et al. } \\
(\mathbf{2 0 0 8})\end{array}$ & $\begin{array}{c}\text { Dahlberg et al. } \\
(\mathbf{2 0 1 5})\end{array}$ & $\begin{array}{c}\text { Our research } \\
\text { (No. of papers) }\end{array}$ \\
\hline $\begin{array}{l}\text { International Conference on Informa- } \\
\text { tion Systems (ICIS) }\end{array}$ & $\checkmark$ & $\checkmark$ & $\checkmark(1)$ \\
\hline $\begin{array}{l}\text { Hawaii International Conference on } \\
\text { System Sciences (HICSS) }\end{array}$ & $\checkmark$ & $\checkmark$ & $\checkmark(7)$ \\
\hline
\end{tabular}




\begin{tabular}{|c|c|c|c|}
\hline Conferences & $\begin{array}{l}\text { Dahlberg, } \\
\text { Mallat, et al. } \\
(2008)\end{array}$ & $\begin{array}{l}\text { Dahlberg et al. } \\
\qquad(2015)\end{array}$ & $\begin{array}{l}\text { Our research } \\
\text { (No. of papers) }\end{array}$ \\
\hline $\begin{array}{l}\text { European Conference on Information } \\
\text { Systems (ECIS) }\end{array}$ & $\checkmark$ & $\checkmark$ & $\checkmark(2)$ \\
\hline $\begin{array}{l}\text { Pacific Asia Conference on Informa- } \\
\text { tion Systems (PACIS) }\end{array}$ & $\checkmark$ & $\checkmark$ & $\checkmark(3)$ \\
\hline $\begin{array}{l}\text { Australasian Conference on Informa- } \\
\text { tion Systems (ACIS) }\end{array}$ & $\checkmark$ & $\checkmark$ & $\checkmark(2)$ \\
\hline IEEE Conference Proceedings & $\checkmark$ & $\checkmark$ & $\checkmark(11)$ \\
\hline $\begin{array}{l}\text { Bled Electronic Commerce Confer- } \\
\text { ence (BLED) }\end{array}$ & $\checkmark$ & $\checkmark$ & $\checkmark(3)$ \\
\hline $\begin{array}{l}\text { International Conference on Elec- } \\
\text { tronic Commerce (ICEC) }\end{array}$ & $\checkmark$ & $\checkmark$ & $\checkmark(9)$ \\
\hline $\begin{array}{l}\text { International Conference on Elec- } \\
\text { tronic Business (ICEB) }\end{array}$ & $\checkmark$ & $\checkmark$ & $\checkmark(0)$ \\
\hline $\begin{array}{l}\text { IADIS International Conference on E- } \\
\text { Commerce }\end{array}$ & $\checkmark$ & $\checkmark$ & $\checkmark(0)$ \\
\hline $\begin{array}{l}\text { IADIS International Conference on } \\
\text { WWW/Internet }\end{array}$ & $\checkmark$ & $\checkmark$ & $\checkmark(0)$ \\
\hline $\begin{array}{l}\text { International Conference on Mobile } \\
\text { Business (ICMB) }\end{array}$ & $\checkmark$ & $\checkmark$ & $\checkmark(9)$ \\
\hline Mobility Roundtable & $\checkmark$ & $\checkmark$ & $\checkmark(9)$ \\
\hline Others & & & $\checkmark(4)$ \\
\hline
\end{tabular}

Table 2. A list of databases used for literature search.

\begin{tabular}{lccc}
\hline Sources & $\begin{array}{c}\text { Dahlberg, } \\
\text { Mallat, et al. } \\
(\mathbf{2 0 0 8})\end{array}$ & $\begin{array}{c}\text { Dahlberg et al. } \\
(\mathbf{2 0 1 5})\end{array}$ & Our research \\
\hline ProQuest Direct & $\checkmark$ & $\checkmark$ & \\
\hline EBSCO & $\checkmark$ & $\checkmark$ & $\checkmark$ \\
\hline ScienceDirect & $\checkmark$ & $\checkmark$ & $\checkmark$ \\
\hline IEEE Xplore & $\checkmark$ & $\checkmark$ & $\checkmark$ \\
\hline ACM Digital Library & $\checkmark$ & $\checkmark$ & $\checkmark$ \\
\hline AIS Electronic Library (AISeL) & $\checkmark$ & $\checkmark$ & $\checkmark$ \\
\hline Google Scholar & $\checkmark$ & & $\checkmark$ \\
\hline M-Lit & $\checkmark$ & $\checkmark$ & $\checkmark$ \\
\hline Scopus & & $\checkmark$ & $\checkmark$ \\
\hline Web of Science & & $\checkmark$ & \\
\hline Emerald Fulltext & & & $\checkmark$ \\
\hline Wiley Online Library & & $\checkmark$ & \\
\hline
\end{tabular}




\subsection{Classification framework}

Due to our focus on methodological and theoretical aspects, a corresponding classification framework was developed (see Table 3). All classification dimensions are discussed below in more detail; however, the most important are research strategy, type of research, methodology, research methods, and theories. Selected articles were classified based on the framework. In order to ensure the accuracy of classification, the review process consisted of two rounds.

Table 3. Classification framework.

\begin{tabular}{ll}
\hline Classification dimension & Categories \\
\hline $\begin{array}{l}\text { Bibliographic and related } \\
\text { data }\end{array}$ & $\begin{array}{l}\text { Author(s), title of the publication, publication date, title of the source, } \\
\text { impact factor of the journal, number of citations in Web of Science } \\
\text { and Google Scholar, type of publication (journal or conference paper) }\end{array}$ \\
\hline Definition & $\begin{array}{l}\text { Developed own definition, use of existing definitions, changed or sum- } \\
\text { marised existing definitions, no definition used } \\
\text { Use cases: Point of Sale (PoS) payment, public transport ticketing, } \\
\text { parking fee payment, etc. } \\
\text { Applied technology }\end{array}$ \\
\hline Research themes & Research themes addressed by the articles \\
\hline Discipline base & Discipline to which papers are related \\
\hline Research strategy & $\begin{array}{l}\text { Analytical: conceptual, mathematical, statistical } \\
\text { Empirical: experimental, statistical, case study }\end{array}$ \\
\hline Type of research & Comparative research, predictive research \\
\hline Methodology & Qualitative, quantitative, mixed \\
\hline Research methods & $\begin{array}{l}\text { Conceptual work, desktop (secondary data) analysis, interviews, focus } \\
\text { groups, survey, case study, development of systems and algorithms, } \\
\text { mathematical modelling, experiment/simulation, prototype, usability } \\
\text { test, empirical test, proof of concept }\end{array}$ \\
\hline Corresponding theories, models, and concepts that are used for anal- \\
ysis
\end{tabular}

Articles were classified and coded by bibliographic and related data. These included impact factor and number of citations in Web of Science and Google Scholar.

In order to capture what researchers imply by "mobile payments", we analysed the use of mobile payments definitions. Applying the same approach as Burgess et al. (2006), a definition was counted only if it was explicitly stated and not implied by the descriptive content. Identified definitions were categorised into original, modified, or existing (Burgess et al., 2006). We also checked what types of use cases and technologies were associated with the mobile payments. 
Then, in order to identify the main research directions, the articles were classified according to the research themes that they address.

The term 'discipline' is defined as "a body of practice that is well supported by occupational groupings that identify with a defined territory of activity" (Burgess et al., 2006, p. 710). Criteria that help to identify a discipline are the disciplinary backgrounds of the authors, research strategies, theoretical models and concepts (Morillo et al., 2003; Woo et al., 2011).

Analysis of methodological approaches in the research of mobile payments includes several dimensions. The selected articles were categorised by theory-building research strategy based on the classification scheme provided by Wacker (1998). This scheme was previously applied in other research areas. The examples are structured literature reviews on supply chain management by Burgess et al. (2006) and seaport research by Woo et al. (2011). Wacker (1998) proposes categorising research strategies into analytical and empirical. Analytical research methods include "logical, mathematical, and/or mathematical-statistical methods" (Wacker, 1998, p. 373) and apply the deductive approach:

- Analytical conceptual research. This is usually case study-based. Examples of such research are (a) introspective research that "describes and explains relationships from past experience to develop theory" (Wacker, 1998, p. 373); (b) conceptual modelling based upon deduced relationships; and (c) hermeneutics research which "deduces facts" from observations (Wacker, 1998, p. 373).

- Analytical mathematical research. Examples of such research are normative analytical modelling research, descriptive analytical modelling, prototyping, experimentations and mathematical simulation. "[T]he models usually are built using formal logic and tested using artificially developed data" (Wacker, 1998, p. 374).

- Analytical statistical research. This is used to integrate "logical/mathematical models from analytical research and statistical models from empiric research into a single integrated theory" (Wacker, 1998, p. 374). These models are used in future empirical statistical tests.

The categories of empirical research are based upon an inductive approach and are the following (Wacker, 1998):

- Empirical experimental research. This is used to determine the effect of independent variables on the dependent variables in the controlled environment.

- Empirical statistical research. The main aim of this type of research is to statistically analyse data collected from large samples of the population. The main methods used for this type of research are interviews, surveys, historical/archival research, expert panels, and Delphi techniques.

- Empirical case study. This type of research is usually focused on a limited sample of analysed companies (Wacker, 1998). The analysis includes a large number of variables and aims to identify new empirical relationships.

In terms of research type, we looked only at whether the paper is comparative or predictive:

- Predictive research aims to predict future behaviour (Adams et al., 2007). 
- Comparative research is used to compare several case studies or developed algorithms (Adams et al., 2007).

Selected articles were classified and coded according to the methodology used (qualitative, quantitative, or mixed), research methods used in the research, and theoretical perspective (that is, theories, models, and concepts applied for analysis). It needs to be mentioned that papers in the research themes and research strategydimensions are mutually exclusive. In other dimensions, the same paper may belong to several categories.

\section{Classification results}

\subsection{Descriptive statistics}

Although the time frame was defined from September 2006 to December 2016, the literature review did not include any paper from 2006. In total, 145 papers were selected (94 journal articles and 51 conference papers). The distribution of analysed papers in the period 2007-2016 is illustrated in Fig. 1. It shows a considerable increase in the number of papers published in recent years, especially in 2014 and 2015.

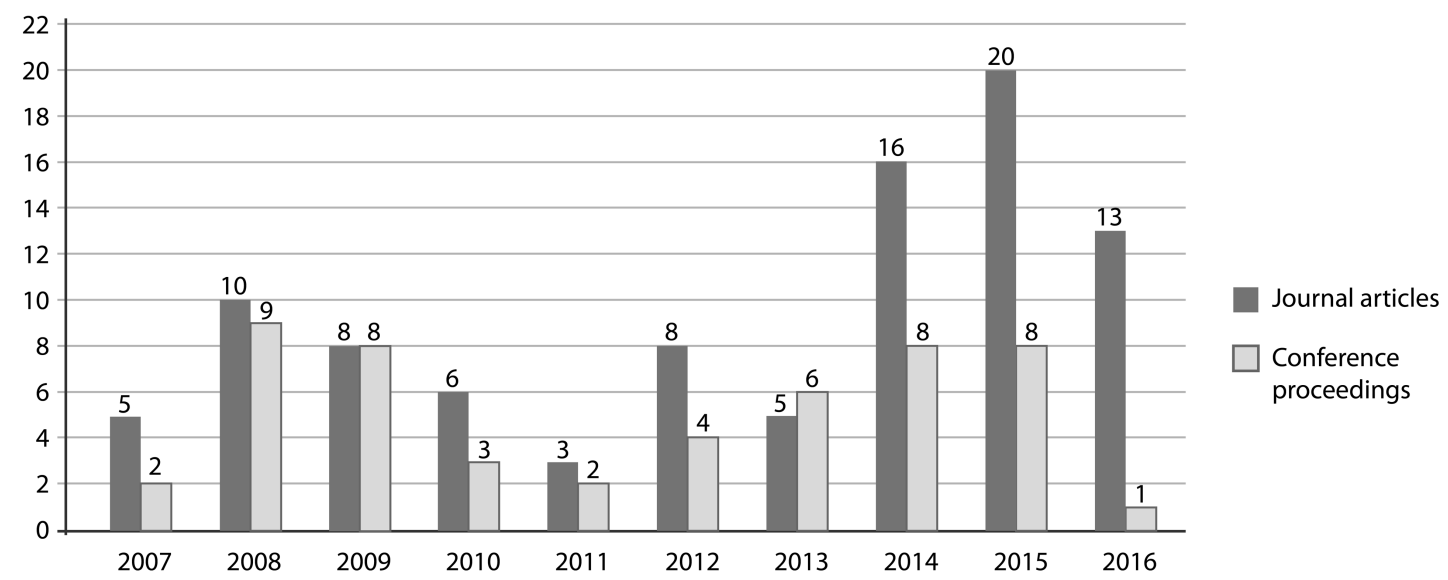

Fig. 1. Distribution of the selected papers over the period 2007-2016.

A list of journals that published at least two articles on mobile payments research is presented in Table 4. More than a half of journal articles have been published in these journals (54 out of 94). The most popular journal is Electronic Commerce Research and Applications. The majority of the journal publications (61 out of 94 , or about $65 \%$ ) were published in journals whose 5year impact factor is 1 and higher (only journals ranked by Web of Science were taken into account).

Table 4. Journals that publish research on the mobile payments.

\begin{tabular}{lccc}
\hline Journal title & No. of papers & $\begin{array}{c}\text { Impact factor } \\
\text { in 2015 }\end{array}$ & $\begin{array}{c}\text { 5-year impact } \\
\text { factor in 2015 }\end{array}$ \\
\hline $\begin{array}{l}\text { Electronic Commerce Research and } \\
\text { Applications }\end{array}$ & 12 & 2.139 & 2.831 \\
\hline
\end{tabular}




\begin{tabular}{|c|c|c|c|}
\hline Journal title & No. of papers & $\begin{array}{l}\text { Impact factor } \\
\text { in } 2015 \\
\end{array}$ & $\begin{array}{l}5 \text {-year impact } \\
\text { factor in } 2015\end{array}$ \\
\hline Computers in Human Behavior & 5 & 2.880 & 3.724 \\
\hline Computer Communications & 4 & 2.099 & 1.732 \\
\hline $\begin{array}{l}\text { Industrial Management and Data } \\
\text { Systems }\end{array}$ & 4 & 1.278 & 1.688 \\
\hline $\begin{array}{l}\text { International Journal of Bank } \\
\text { Management }\end{array}$ & 4 & $\mathrm{n} / \mathrm{a}$ & $\mathrm{n} / \mathrm{a}$ \\
\hline Wireless Personal Communications & 4 & 0.701 & 0.669 \\
\hline Info & 3 & $\mathrm{n} / \mathrm{a}$ & $\mathrm{n} / \mathrm{a}$ \\
\hline $\begin{array}{l}\text { Information Systems and e-Business } \\
\text { Management }\end{array}$ & 3 & 0.953 & 1.000 \\
\hline $\begin{array}{l}\text { International Journal of Mobile } \\
\text { Communications }\end{array}$ & 3 & 0.765 & 1.040 \\
\hline Computer Law \&S Security Review & 2 & 0.373 & - \\
\hline Computing & 2 & 0.872 & 1.144 \\
\hline Information $\&$ Management & 2 & 2.163 & 3.175 \\
\hline Journal of Information Technology & 2 & 4.775 & 6.189 \\
\hline Mobile Information Systems & 2 & 1.462 & 1.221 \\
\hline $\begin{array}{l}\text { Transportation Research Part C: } \\
\text { Emerging Technologies }\end{array}$ & 2 & 3.075 & 3.631 \\
\hline Total & 54 & & \\
\hline
\end{tabular}

\subsection{Definition and scope of the mobile payments}

In almost half of the articles (46\%) no definition of mobile payments was used (see Table 5). The second largest group used existing definitions (23\%). In $21 \%$ of papers, researchers have proposed their own definitions; a minority (10\%) have changed or tried to summarise the existing definitions.

The two most referenced definitions are those proposed by Au and Kauffman (2008) and Dahlberg, Mallat, et al. (2008). They are provided in Table 6.

Table 5. Approaches to definition of mobile payments.

\begin{tabular}{lcc}
\hline Approach & Frequency (papers) & Frequency (\%) \\
\hline Developed own definition & 31 & $21 \%$ \\
\hline Use of existing definition & 33 & $23 \%$ \\
\hline Changed or summarised existing definition & 14 & $10 \%$ \\
\hline No definition used & 67 & $46 \%$ \\
\hline Total & 145 & $100 \%$ \\
\hline
\end{tabular}


Table 6. The most commonly used definitions of mobile payments.

\begin{tabular}{ll}
\hline Study & Definition \\
\hline $\begin{array}{l}\text { Au and Kauffman, 2008 } \\
\text { (referred to in 11 } \\
\text { publications) }\end{array}$ & $\begin{array}{l}\text { A mobile payment or m-payment is any payment where a mobile device is } \\
\text { used to initiate, authorise, and confirm an exchange of financial value in } \\
\text { return for goods and services }\end{array}$ \\
\hline $\begin{array}{l}\text { Dahlberg, Mallat, et al., } \\
\begin{array}{l}\text { 2008 (referred to in 14 } \\
\text { publications) }\end{array}\end{array}$ & $\begin{array}{l}\text { Mobile payments are payments for goods, services, and bills with a mobile } \\
\text { device (such as a mobile phone, smartphone, or personal digital assistant) } \\
\text { by taking advantage of wireless and other communication technologies. }\end{array}$ \\
\hline
\end{tabular}

Dahlberg, Mallat, et al. (2008, p. 165-166) have specified the following use cases of mobile payments: payments for digital content, tickets, parking fees, transport fares, and "to access electronic payment services to pay bills and invoices." In the majority of papers (95 papers), authors do not specify the use case of the mobile payments (see Appendix A). The most referenced use cases for mobile payments are payments at PoS (in 29 papers) and public transport ticketing (in 15 papers).

Wireless and communication technologies used for mobile payments were specified in $60 \%$ of the papers (see Appendix A). The most referenced technologies are: (i) near-field communication (NFC), (ii) SMS, and (iii) WAP and mobile internet. Other technologies have received less attention.

\subsection{Research themes}

The categorisation of the selected papers showed that the dominant research themes (see Fig. 2) are:

- Customer adoption (53 papers);

- Technological aspects (48 papers);

- Business aspects (32 papers).

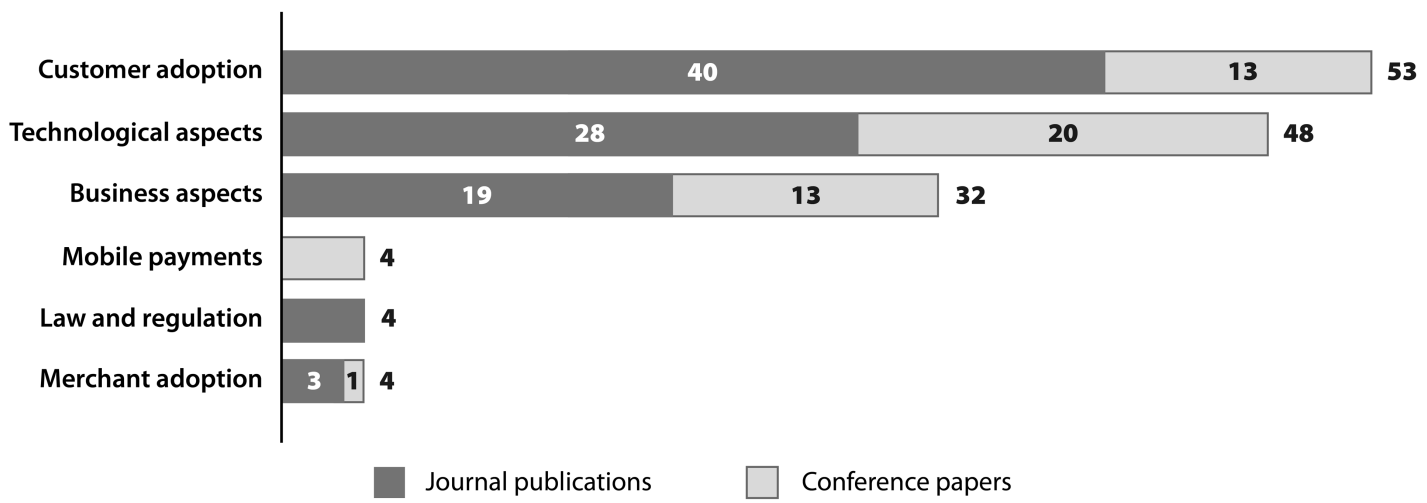

Fig. 2. Distribution of mobile payments articles by research themes.

Just a few articles (12 articles) have addressed other themes, which are law and regulation, merchant adoption, and mobile payments. Due to the small analysis sample, it is impossible to identify trends in these categories. For this reason, these papers are presented in the general analysis part but not discussed separately. 


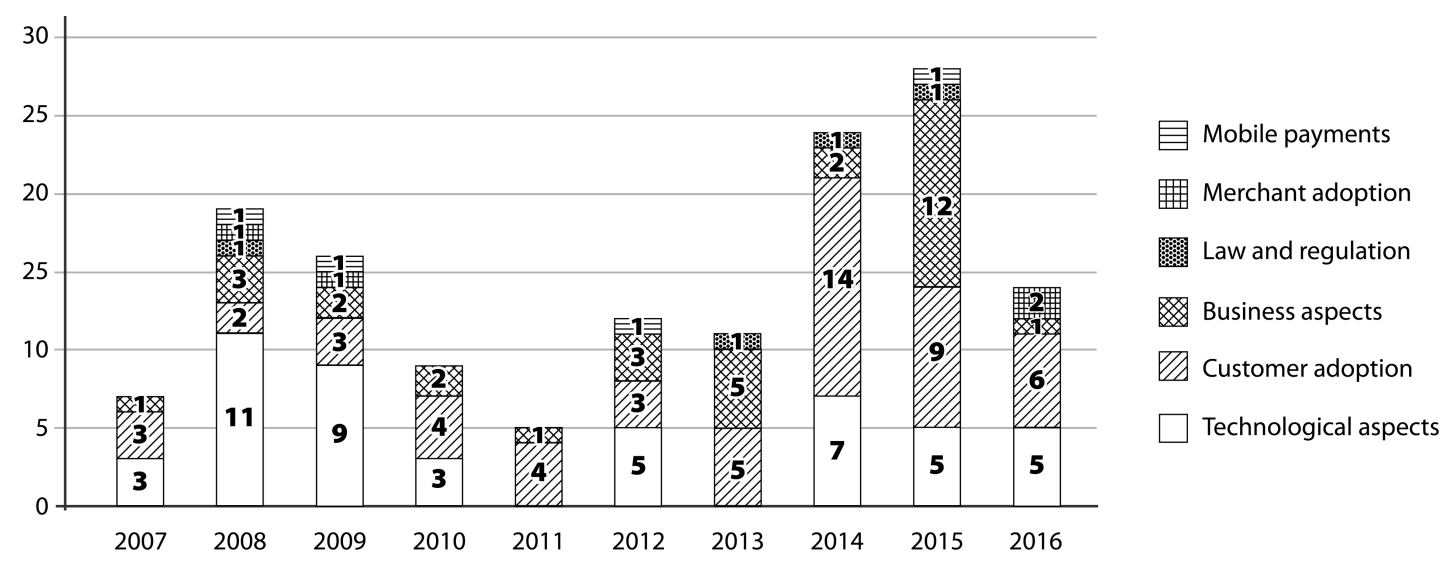

Fig. 3. Distribution of research themes by years.

One interesting finding is that the number of articles addressing technological aspects of mobile payments peaked in 2008 and has been decreasing since then (see Fig. 3). The average number of published papers on customer adoption remained at the same level (about three papers per year) throughout 2007-2013 and reached its maximum in 2014 (14 papers). The number of papers addressing business aspects peaked in 2015 .

\subsection{Discipline base}

In this study, papers were categorised into seven disciplines which appeared the most relevant to mobile payments research. The disciplines are economics, organisational relations, strategic management, marketing/services, psychology/sociology, law, and software engineering (see Table 7).

Table 7. Discipline base in mobile payments research.

\begin{tabular}{lccccccc}
\hline Discipline & CA $^{*}$ & TA & BA & Law & MA & MP & Total \\
\hline Economics & 0 & 0 & 7 & 1 & 1 & 1 & 10 \\
\hline Organisational relations & 0 & 0 & 13 & 0 & 0 & 0 & 13 \\
\hline Strategic management & 0 & 0 & 18 & 0 & 1 & 0 & 19 \\
\hline Marketing/services & 2 & 0 & 5 & 0 & 2 & 1 & 10 \\
\hline Psychology/sociology & 51 & 0 & 2 & 0 & 0 & 0 & 53 \\
\hline Law & 0 & 0 & 0 & 3 & 0 & 0 & 3 \\
\hline Software engineering & 0 & 48 & 0 & 0 & 0 & 2 & 50 \\
\hline Total & & & & & & $158^{* *}$ \\
\hline
\end{tabular}

${ }^{*}$ CA: Customer adoption; TA: Technological aspects; BA: Business aspects;

Law: Law and regulation; MA: Merchant adoption; MP: Mobile payments.

** Within the 145 papers, some were situated in more than one discipline and were placed in multiple categories. 
The aggregated results show that dominant disciplines are psychology/sociology and software engineering (53 and 50 papers, respectively). Strategic management follows with 19 papers. A few papers have focused on other economic and business-related disciplines (i.e. economics, marketing/services, and organisational relations). However, business aspects was the only group of papers containing eight articles which were classified as situated in several disciplines.

Additionally, it is possible to notice some correlation between the research theme and the discipline. For example, almost all papers on customer adoption are based in psychology/sociology. In the same way, all papers on technological aspects are focused on software engineering. Papers on business aspects are based in various economic and business disciplines.

\subsection{Research strategy and type of research}

We have classified papers according to the theory-building research strategy using classification proposed by Wacker (1998). The proposed research strategy categories were identified in 98 papers; 47 papers dedicated to technological aspects of mobile payments are focused on the development of technical solutions and do not fall under the applied categorisation.

As presented in Table 8, the majority of the research on mobile payments (75.5\%) is analytical, based on the deductive approach, the majority being statistical. About 25\% of papers are empirical studies based on the inductive approach, dominated by case studies. The analytical statistical strategy has been applied in the majority of the research (in about $47 \%$ of papers) (see Fig. 4). Analytical conceptual and empirical case study research strategies were applied in $26.5 \%$ and $22.4 \%$ of papers respectively. Analytical mathematical and empirical statistical studies are not common and empirical experimental studies have never been used in mobile payments research.

Table 8. Research strategy in mobile payments research.

\begin{tabular}{|c|c|c|c|c|c|c|c|}
\hline Strategy & Total & $\mathrm{CA}^{*}$ & TA & BA & Law & MA & MP \\
\hline Analytical (total) & $74(75.5 \%)$ & & & & & & \\
\hline Conceptual & $26(26.5 \%)$ & 2 & 2 & 15 & 3 & 2 & 2 \\
\hline Mathematical & $2(2.0 \%)$ & 0 & 0 & 1 & 0 & 1 & 0 \\
\hline Statistical & $46(46.9 \%)$ & 46 & 0 & 0 & 0 & 0 & 0 \\
\hline Empirical (total) & $24(24.5 \%)$ & & & & & & \\
\hline Experimental & $0(0 \%)$ & 0 & 0 & 0 & 0 & 0 & 0 \\
\hline Statistical & $2(2.0 \%)$ & 2 & 0 & 0 & 0 & 0 & 0 \\
\hline Case study & $22(22.4 \%)$ & 3 & 0 & 16 & 1 & 1 & 1 \\
\hline Total & $98(100 \%)$ & 53 & 2 & 32 & 4 & 4 & 3 \\
\hline \multicolumn{8}{|l|}{ Of which: } \\
\hline Comparative & $36(36.7 \%)$ & 4 & 20 & 10 & 0 & 0 & 2 \\
\hline Predictive & $1(1.0 \%)$ & 1 & 0 & 0 & 0 & 0 & 0 \\
\hline
\end{tabular}

* CA: Customer adoption; TA: Technological aspects; BA: Business aspects; Law: Law and regulation; MA: Merchant adoption; MP: Mobile payments. 


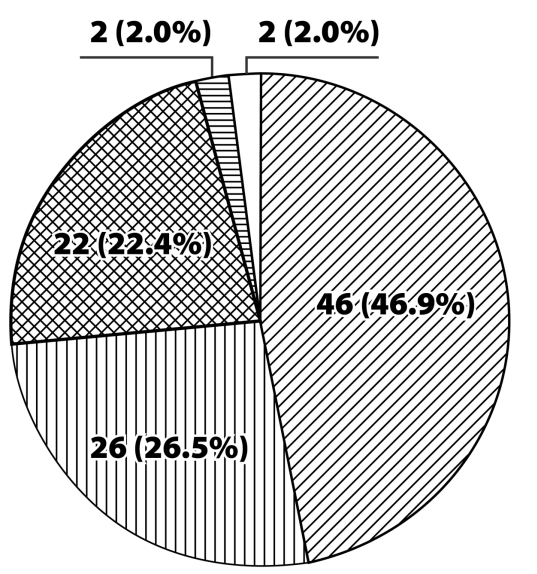

\section{Analytical statistical \\ 血 Analytical conceptual \\ Empirical case study \\ 目 Analytical mathematical \\ $\square$ Empirical statistical}

Fig. 4. Research strategies in mobile payments research.

An analytical statistical strategy is dominant in the customer adoption studies. The research strategies applied in studies on business aspects of mobile payments represent an almost equal split between analytical conceptual and empirical case studies.

Comparative studies are mainly used in studies on technological (20 papers out of total 50) and business (10 papers out of total 32) aspects of mobile payments. Only one study appeared to be predictive.

\subsection{Methodology, research methods, and theoretical background}

Regarding the methodology used, quantitative research is mainly applied to study consumer adoption. Qualitative research is the most common approach in studies on business aspects. A small number of qualitative or quantitative research in papers on mobile payments technology can be explained by a focus on solution development. A summary of research methodologies used is presented in Table 9 .

Table 9. Research methodology used in mobile payments research.

\begin{tabular}{lccccccc}
\hline $\begin{array}{l}\text { Methodology } \\
\text { (No. of papers) }\end{array}$ & $\begin{array}{c}\text { CA* } \\
(53)\end{array}$ & $\begin{array}{c}\text { TA } \\
(48)\end{array}$ & $\begin{array}{c}\text { BA } \\
(32)\end{array}$ & $\begin{array}{c}\text { Law } \\
(4)\end{array}$ & $\begin{array}{c}\text { MA } \\
(4)\end{array}$ & $\begin{array}{c}\text { MP } \\
(4)\end{array}$ & $\begin{array}{c}\text { Total } \\
(145 / 100 \%)\end{array}$ \\
\hline Qualitative & 5 & 0 & 23 & 2 & 2 & 1 & $33(22.8 \%)$ \\
\hline Quantitative & 44 & 0 & 1 & 0 & 1 & 0 & $46(31.7 \%)$ \\
\hline Mixed & 4 & 2 & 1 & 0 & 1 & 0 & $8(5.5 \%)$ \\
\hline Total & 53 & 2 & 25 & 2 & 4 & 1 & $87(60.0 \%)$ \\
\hline
\end{tabular}

* CA: Customer adoption; TA: Technological aspects; BA: Business aspects; Law: Law and regulation; MA: Merchant adoption; MP: Mobile payments.

Furthermore, the analysed articles were categorised by research methods used (see Table 10; see details in Appendix B, Table B.1-B.6). The top five most used research methods are: (i) survey (used in $34.5 \%$ of papers); (ii) development of systems and algorithms (used in $29.7 \%$ of papers); (iii) conceptual work (used in $25.5 \%$ of papers); (iv) interviews (used in $22.8 \%$ of papers); and (v) case study (used in $19.3 \%$ of papers). In the majority of studies, researchers tend to apply a combination of different methods. 
Table 10. Research methods used in mobile payments research.

\begin{tabular}{lccccccc}
\hline $\begin{array}{l}\text { Methods } \\
\text { No. of papers }\end{array}$ & $\begin{array}{c}\text { CA* } \\
(53)\end{array}$ & $\begin{array}{c}\text { TA } \\
(48)\end{array}$ & $\begin{array}{c}\text { BA } \\
(32)\end{array}$ & $\begin{array}{c}\text { Law } \\
(4)\end{array}$ & $\begin{array}{c}\text { MA } \\
(4)\end{array}$ & $\begin{array}{c}\text { MP } \\
(4)\end{array}$ & $\begin{array}{c}\text { Total } \\
(145 / 100 \%)\end{array}$ \\
\hline Survey & 47 & 1 & 2 & 0 & 0 & 0 & $50(34.5 \%)$ \\
\hline $\begin{array}{l}\text { Development of } \\
\text { systems and } \\
\text { algorithms }\end{array}$ & 0 & 43 & 0 & 0 & 0 & 0 & $43(29.7 \%)$ \\
\hline Conceptual work & 1 & 5 & 25 & 3 & 3 & 2 & $37(25.5 \%)$ \\
\hline Interviews & 7 & 2 & 19 & 1 & 3 & 1 & $33(22.8 \%)$ \\
\hline Case study & 3 & 0 & 21 & 2 & 1 & 1 & $28(19.3 \%)$ \\
\hline $\begin{array}{l}\text { Desktop analysis } \\
\text { Prototype }\end{array}$ & 1 & 1 & 19 & 1 & 3 & 1 & $25(17.2 \%)$ \\
\hline $\begin{array}{l}\text { Experiment/ } \\
\text { simulation }\end{array}$ & 0 & 18 & 0 & 0 & 0 & 1 & $19(13.1 \%)$ \\
\hline Usability test & 5 & 10 & 1 & 0 & 0 & 0 & $16(11.0 \%)$ \\
\hline Focus groups & 0 & 6 & 0 & 0 & 0 & 1 & $7(4.8 \%)$ \\
\hline Empirical test & 3 & 0 & 3 & 0 & 0 & 0 & $6(4.1 \%)$ \\
\hline $\begin{array}{l}\text { Mathematical } \\
\text { modelling }\end{array}$ & 3 & 0 & 0 & 0 & 0 & 0 & $3(2.1 \%)$ \\
\hline \begin{tabular}{l} 
Proof of concept \\
\hline
\end{tabular} & 0 & 0 & 1 & 0 & 1 & 0 & $2(1.4 \%)$ \\
\hline
\end{tabular}

* CA: Customer adoption; TA: Technological aspects; BA: Business aspects; Law: Law and regulation; MA: Merchant adoption; MP: Mobile payments.

Additionally, there is a clear preference of methods for two themes: (i) survey is the most common approach for studies on customer adoption and (ii) development of systems and algorithms, and prototyping are mostly used in papers on technology. Research on mobile payments business issues is rich in conceptual work and theoretical discussions and is mainly based on case studies, wherein data are collected with the help of interviews and secondary data sources (desktop analysis).

In total, theoretical background is present in the majority of papers (about 57\%) (see Table 11). Theory is discussed in almost all papers on customer adoption and business aspects. It is not common to discuss theory in papers on technology. More details on the theoretical approaches used in papers on customer adoption and business aspects are discussed below (see Section 4.1 and Section 4.3).

Table 11. Theoretical base in research on mobile payments.

\begin{tabular}{lccccccc}
\hline Theoretical base & CA $^{*}$ & TA & BA & Law & MA & MP & Total \\
\hline Theory used & 51 & 1 & 27 & 0 & 3 & 1 & $83(57.2 \%)$ \\
\hline No theory & 2 & 47 & 5 & 4 & 1 & 3 & $62(42.8 \%)$ \\
\hline Total & 53 & 48 & 32 & 4 & 4 & 4 & $145(100 \%)$ \\
\hline
\end{tabular}

* CA: Customer adoption; TA: Technological aspects; BA: Business aspects; Law: Law and regulation; MA: Merchant adoption; MP: Mobile payments. 


\section{Methodological and theoretical perspectives within identified research themes}

This section is dedicated to more detailed analysis of the methodological and theoretical perspectives used within each of the identified mobile payments research themes (i.e. customer adoption, technological and business aspects). The distribution of papers on these themes during 2007-2016 is presented in Fig. 5.

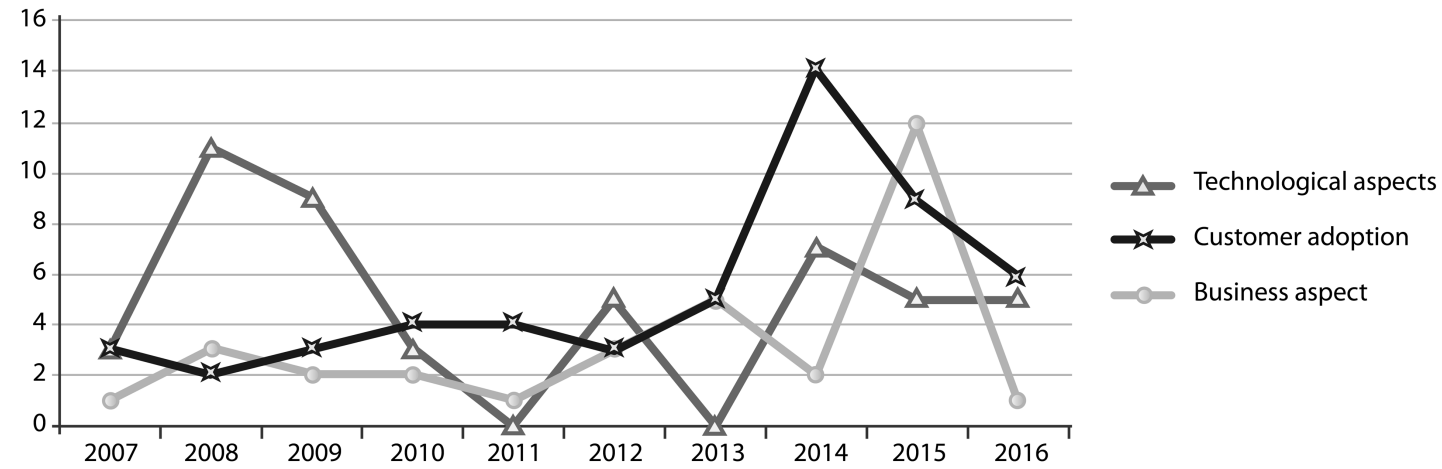

Fig. 5. Distribution of articles on the main themes during 2007-2016.

\subsection{Customer adoption aspects of mobile payments}

The theme of customer adoption represents one of the major streams in the academic research on mobile payments with a total of 53 publications (40 journal articles and 13 conference proceedings). The research, methodological, and theoretical aspects that are applied within this theme are discussed below.

Research and methodological aspects. The majority of publications are analytical statistical, using quantitative methodology (see Table 12). Survey is a prevailingmethod used for data collection. Different types of survey include questionnaires, which are printed and sent by post, published online, or performed over the telephone. Other types of data collection (i.e. desktop analysis, focus group discussions, and interviews) are less common. In three studies, users had the opportunity to empirically test mobile payments services. Finally, one group of researchers (Liebana-Cabanillas et al., 2014a, 2014b, 2014c; Liebana-Cabanillas et al., 2015; Ramos-de-Luna et al., 2016) has used a social network (Facebook) to perform a number of studies identifying factors influencing the intention to use mobile payments. The respondents were invited to watch a video illustrating the use of a mobile payments service and then to answer questions.

Table 12. Summary of research and methodology aspects (based on Tables 8, 9, and 10).

\begin{tabular}{ll}
\hline Dimension & Main trends \\
\hline Research strategy & Analytical statistical $-86.8 \%$ (46 papers out of 53$)$ \\
\hline Research methodology & Quantitative $-83.0 \%$ (44 papers out of 53$)$ \\
\hline Research method & Survey $-88.7 \%(47$ papers out of 53$)$ \\
\hline
\end{tabular}

There are four comparative papers: (i) Cheng and Huang (2013) compare how different technologies (mobile internet and QR code) used for public transportation ticket purchases affect the adoption of a mobile ticketing system; (ii) Dahlberg and Öörni (2007) develop and compare 
two models for the adoption of different services (mobile payments and electronic invoicing); (iii) Slade et al. (2015) compare the results of the application of two adoption models (UTAUT2 and its extension); and (iv) Viehland and Leong (2007) compare the adoption of mobile payments in two countries (New Zealand and the USA). In addition, there is one predictive article: Brakewood et al. (2014) forecast the adoption of mobile payments in the mobile transport ticketing domain.

The dominant research problem that has been the focus for researchers is related to understanding how different factors influence customer intention to use or adopt mobile payments (42 papers out of 53). A few publications have investigated factors that influence (i) actual adoption (three papers); (ii) post-adoption (two papers); (iii) willingness to use smartphones for mobile payments (two papers); and (iv) sources of perceived risks (two papers) (see Appendix C, Table C.1).

Theoretical perspectives. The most common approach of researchers investigating customer adoption issues is building onto existing adoption models. The Technology Adoption Model (TAM) and its variations - theUnified Theory of Acceptance and Use of Technology (UTAUT) and UTAUT2 - are the most commonly used approaches (see Table 13; details in Appendix C, Table C.2). The theory of Diffusion of Innovations (DoI) is used relatively less frequently compared to TAM. Adoption theories are also used in combination with other theories - for example, the Theory of Reasoned Action (TRA) and the Theory of Planned Behaviour (TPB).

Only a few articles use other theories to study adoption phenomena. Examples are works by Cocosila and Trabelsi (2016), de Kerviler et al. (2016), Liu et al. (2013), and Yang et al. (2015) that have brought perceived value and perceived risk into focus under the analysis of customer adoption behaviour.

Table 13. Theoretical base used in research on customer adoption of mobile payments.

\begin{tabular}{llc}
\hline Discipline & Theories, models, concepts & Frequency \\
\hline Psychological/sociological & Adoption theories & \\
& DoI (and other theories) & 3 \\
& TAM (and other theories) & 19 \\
& TAM and DoI (and other theories) & 9 \\
& UTAUT (and other theories) & 3 \\
& TAM and UTAUT (and other theories) & 5 \\
& UTAUT2 (and other theories) & 3 \\
& Other theories & 9 \\
\hline Marketing/services & No theory used & 2 \\
\hline & Total & 53 \\
\hline
\end{tabular}

The majority of researchers investigating the adoption of mobile payments extend the existing models with new constructs. The analysed constructs can be classified in three categories:

1. Service characteristics. The most used are perceived ease of use, usefulness, risk, security, compatibility, and cost.

1. Consumer characteristics. The most used are trust in actors and services and knowledge of technology.

2. External factors. The most used are social influence and subjective norm.

A large number of constructs have been proposed and analysed by researchers but a considerable 
number of them have been tested only once or twice. These constructs are omitted in the presented summary of results (see Table 14).

Table 14. Constructs used in adoption studies (details in Appendix C, Table C.3-C.5).

\begin{tabular}{lc}
\hline Construct & Frequency \\
\hline Service characteristics & \\
\hline Perceived ease of use & 31 \\
\hline Perceived usefulness & 29 \\
\hline Perceived risk (security, privacy, financial) & 20 \\
\hline Perceived security & 16 \\
\hline (Perceived) compatibility & 16 \\
\hline Cost (perceived) & 13 \\
\hline Performance expectancy & 8 \\
\hline Convenience & 7 \\
\hline Relative advantage & 6 \\
\hline Effort expectancy & 6 \\
\hline Added value services/additional value & 3 \\
\hline Customer characteristics & \\
\hline Trust in actors or services & 25 \\
\hline Effect of demographic data & 15 \\
\hline Personal innovativeness in information technology & 11 \\
\hline Knowledge or previous experience of technology or service & 10 \\
\hline Attitude towards use & 9 \\
\hline Mobility/individual mobility & 5 \\
\hline Self-efficacy & 5 \\
\hline Hedonistic motivation (fun, enjoyment, entertainment) & 5 \\
\hline Behavioural intention (to use/adopt) & 3 \\
\hline External factors & \\
\hline Social influence & 15 \\
\hline Subjective norm & 8 \\
\hline Facilitating conditions & 6 \\
\hline External influence & 3 \\
\hline Use situation/context & 3 \\
\hline & \\
\hline
\end{tabular}

\subsection{Technological aspects of mobile payments}

Technological aspects of mobile payments comprise the second most researched theme in the academic research. We identified 48 publications (28 journal articles and 20 conference proceedings).

Research and methodological aspects. The majority of publications propose new technical systems, architectures, and protocols. These papers do not apply theory-building research strategies, qualitative or quantitative methodologies. However, within this theme there are 20 
comparative papers. Thus, it is a common approach to perform a comparative analysis of newly proposed and existing solutions.

Table 15. Summary of research and methodology aspects (based on Tables 8, 9, and 10).

\begin{tabular}{ll}
\hline Dimension & Main trends \\
\hline Research strategy & - \\
\hline Research methodology & - \\
\hline Research method & Development of systems and algorithms $-89.6 \%$ (43 papers out of 48$)$ \\
& Prototype $-37.5 \%(18$ papers out of 48$)$ \\
& Simulation $-20.8 \%(10$ papers out of 48$)$ \\
\hline
\end{tabular}

Development of systems and algorithms is the main used method (see Table 15). In 18 studies, researchers have developed a prototype; six prototypes were evaluated through usability tests. Simulation of developed solutions is also commonly applied.

The major problem that has been examined in the papers is related to the security of mobile payments (see Fig. 6; details in Appendix D). Different aspects of security issues were discussed in 40 articles out of 48. Proposals of new mobile payments systems and architectures (25 articles) represent the second most popular research topic; development of new protocols is addressed by 17 studies.

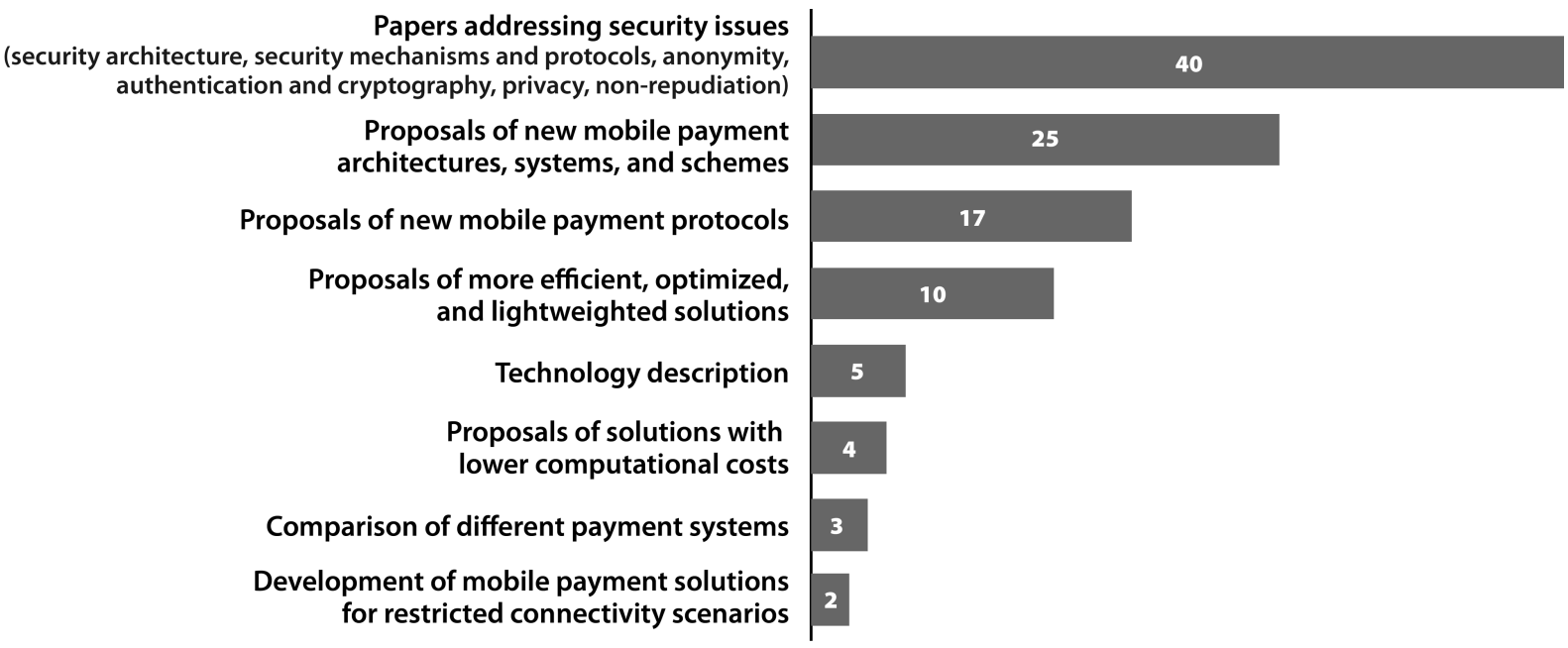

Fig. 6. Classification of papers on technology by topics.

Theoretical perspectives. Commonly, there is no theoretical background in the papers on technology. However, some papers include a review of related work that is primarily based on a review of the state of art in mobile payments in order to set the scene. This includes overviews of previously developed protocols, architectures, solutions and implemented research initiatives, comparisons of different technologies, and overviews of security levels.

\subsection{Business aspects of mobile payments}

The business aspects theme comprises 32 publications (19 journal articles and 13 conference proceedings). This is therefore the third most popular topic in the contemporary academic research on mobile payments. 
Research and methodological aspects. The most common research strategies within papers on business aspects are empirical case studies and analytical conceptual (see Table 16). The majority of papers are based upon qualitative methodology. The studies within this theme are especially rich in conceptual theoretical works. Case studies have been the most common approach for both deductive and inductive theory-building. Moreover, ten papers are multiple case studies providing comparative analysis across the cases. Desktop analyses and interviews are the main methods used for data collection.

The main problem that has been in the focus of researchers is related to analysis of the business ecosystem of mobile payments, the main actors and their roles (23 papers out of 32 ). The second most addressed problem is related to different aspects of the business model (11 papers out of 32). Ten papers provide an analysis of mobile payments markets. The same number of papers explore collaboration issues in inter-firm relationships. The summary of addressed themes is presented in Fig. 7 (more details in Appendix E, Table E.1).

Table 16. Summary of research and methodology aspects (based on Tables 8, 9, and 10).

\begin{tabular}{ll}
\hline Dimension & Main trends \\
\hline Research strategy & Empirical case study $-50.0 \%(16$ papers out of 32$)$ \\
& Analytical conceptual $-46.9 \%(15$ papers out of 32$)$ \\
\hline Research methodology & Qualitative $-71.9 \%(23$ papers out of 32$)$ \\
\hline Research method & Conceptual work $-78.1 \%(25$ papers out of 32$)$ \\
& Case study $-65.6 \%(21$ papers out of 32$)$ \\
& Desktop analysis $-59.4 \%(19$ papers out of 32$)$ \\
& Interviews $-59.4 \%(19$ papers out of 32$)$ \\
\hline
\end{tabular}

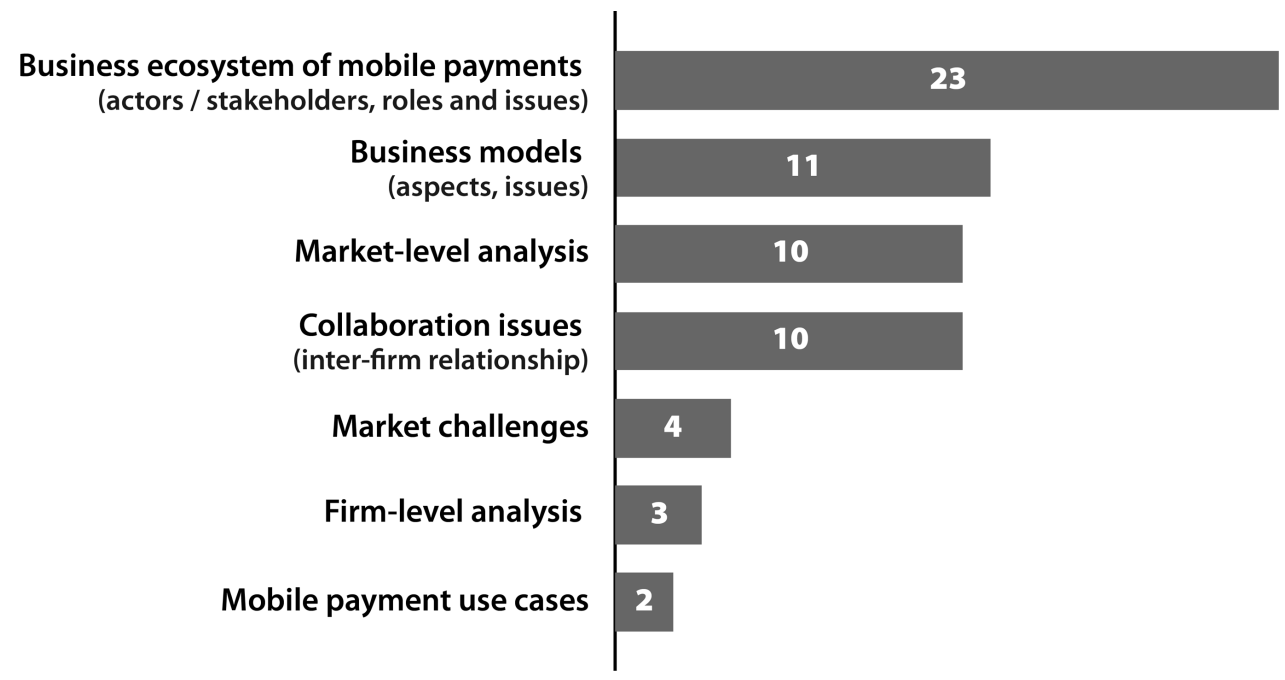

Fig. 7. Classification of papers on business aspects by topics.

Theoretical perspectives. The most frequently applied category of economic and businessrelated theories is rooted in strategic management (21 papers). It is closely followed by theories addressing inter-organisational relations (18 papers). A smaller number of papers (10) apply economic theories (see Table 17; more details in Appendix E, Table E.2). 
Table 17. Theoretical base used in research on business aspects of mobile payments.

\begin{tabular}{llc}
\hline Discipline & Theories, models, concepts & Frequency \\
\hline Economics & Network economies & 3 \\
& Industry evolution, dominant design & 3 \\
& Switching costs & 2 \\
& Other theories & 2 \\
\hline Organisational relations & Business ecosystems & 5 \\
& Network perspective & 2 \\
& Co-opetition & 2 \\
& Other theories & 5 \\
& No theory & 4 \\
\hline Strategic management & Business model & 6 \\
& Platforms, two-sided market & 8 \\
& Resource-based view & 3 \\
& Other strategy theories & 4 \\
\hline Marketing/services & Different theories & 3 \\
& No theory & 2 \\
\hline Psychology/sociology & Adoption theory & 2 \\
\hline & Total & $56^{*}$ \\
\hline
\end{tabular}

* Some papers were situated in more than one discipline and used more than one theoretical perspective; they were therefore placed in multiple categories.

The authors of the majority of publications in this category (22 papers out of 32) have proposed new frameworks for analysis (see Table 18). Only a few of these models have been further applied in the studies of other researchers.

Table 18. Theoretical frameworks proposed by researchers studying mobile payments.

\begin{tabular}{ll}
\hline Proposed theoretical framework & $\begin{array}{l}\text { Applied in works of } \\
\text { others }\end{array}$ \\
\hline
\end{tabular}

Mobile payment models (Van Bossuyt and Van Hove, 2007)

A robust framework for the analysis of economic issues for disruptive Ondrus et al., 2009 technologies (Au and Kauffman, 2008)

Dominant design emergence process (Dahlberg, Huurros, et al., Ondrus et al., 2009 2008)

The mobile payment modelling approach (MPMA) (Pousttchi, 2008)

M-payment business model framework (Pousttchi et al., 2009)

Dynamic model of the diffusion stages of a mobile payment solution Ondrus and Lyytinen, 2011

(Ondrus et al., 2009)

Framework for the study of collaboration and competition in the digital payment ecosystem (Hedman and Henningsson, 2012)

Mobile payments integration framework (Carton et al., 2012)

Framework for the analysis of large-scale infrastructure management processes (Andersson et al., 2013) 


\begin{tabular}{ll}
\hline Proposed theoretical framework & $\begin{array}{l}\text { Applied in works of } \\
\text { others }\end{array}$ \\
\hline Co-opetition (Andersson et al., 2013) & \\
\hline Digital payment framework (Kazan and Damsgaard, 2013) & \\
\hline NFC ecosystem model (Ok et al., 2013) & \\
\hline Discontinuance of collective action (de Reuver et al., 2015) & \\
\hline $\begin{array}{l}\text { Market (non)emergence at the convergence of distinct industries } \\
\text { (Ozcan and Santos, 2015) }\end{array}$ & Gannamaneni et al., 2015; \\
\hline Service business model canvas (Zolnowski et al., 2014) & Ondrus, 2015 \\
\hline $\begin{array}{l}\text { The mobile payment market cooperation (MPMC) framework } \\
\text { (Hedman and Henningsson, 2015) }\end{array}$ & \\
\hline A decision model for platform openness (Ondrus et al., 2015) & \\
\hline Partnership management canvas (Dennehy et al., 2015) & \\
\hline Investment decision model (Kauffman et al., 2015) & \\
\hline $\begin{array}{l}\text { Entry and expansion strategy framework (Staykova and Damsgaard, } \\
\text { 2015) }\end{array}$ & \\
\hline $\begin{array}{l}\text { RISE model explaining how initiators create payment platform } \\
\text { ecosystem (Zhong and Nieminen, 2015) }\end{array}$ & \\
\hline $\begin{array}{l}\text { StReS model to analyse the business ecosystem on three levels: } \\
\text { structure, resources, and strategy (Guo and Bouwman, 2016) }\end{array}$ &
\end{tabular}

\subsection{Trends in the evolution of the theoretical base}

In the previous sections, we have provided an overview of the theoretical background used for customer adoption and business-related studies. It is possible to notice that the traditions of the corresponding discipline make an impact on the selection of theories within these two major themes. We discuss this in more detail below.

Customer adoption studies, being examples of psychological and sociological disciplines, are based upon adoption theories' concepts. During the period 1998-2006, the theoretical base comprised TAM, its extension (UTAUT), and DoI (Dahlberg, Mallat, et al., 2008). During 2007-2016, the range of the most commonly used theories was widened with UTAUT2 (see Fig. 8). Additionally, researchers were extending existing adoption models with constructs of other theories - for instance, TRA and TPB. Studies have confirmed that perceived ease of use, usefulness, trust, and security and privacy risks are the major factors affecting the intention to adoption (this is in line with Dahlberg, Mallat, et al., 2008; Dahlberg et al., 2015). However, the common approach is to use the existing theories but not to develop a specific theory specifically addressing mobile payments adoption. 


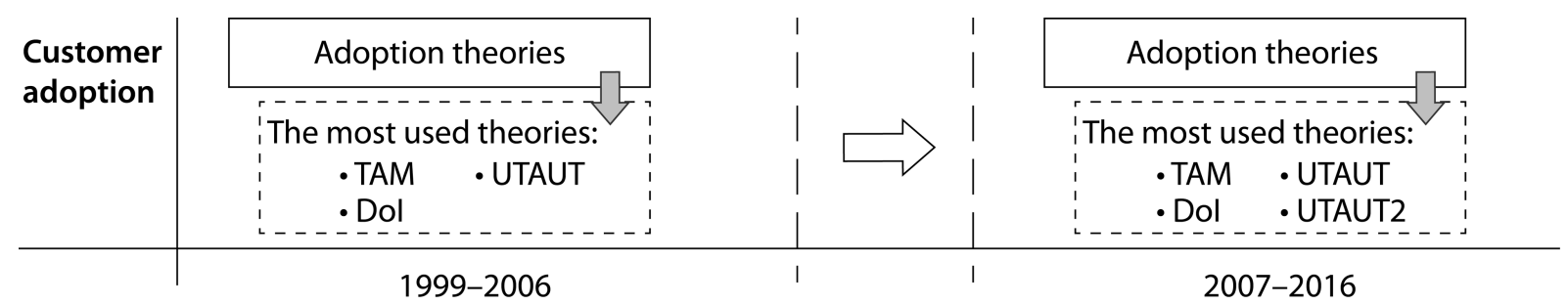

Fig. 8. Dynamic of theoretical base evolution within customer adoption theme.

The more interesting findings are related to use of a theoretical background in studies on businessrelated aspects of mobile payments (see Fig. 9). The first papers that were classified as dedicated to this theme within the period 1999-2007 used no theoretical background. These papers represented inductive research with proposed analysis frameworks based on empirical data. Just a few such papers appeared during 2008-2011. However, during this period, the common approach towards use of a theoretical background started to change: that is, researchers started using a set of theories for the development of specific analysis frameworks applicable in the domain of mobile payments. During this period, the business model was the most used concept.

Starting from 2012, researchers continued using a mix of theories for their developed frameworks. However, the focus of their interests shifted to the use of platform, ecosystem, and business network theories. One of the explanations for such a shift might be the limited ability of the business model concept to explain complex business relationships between companies providing mobile payments services and complex strategic issues that business actors need to solve.

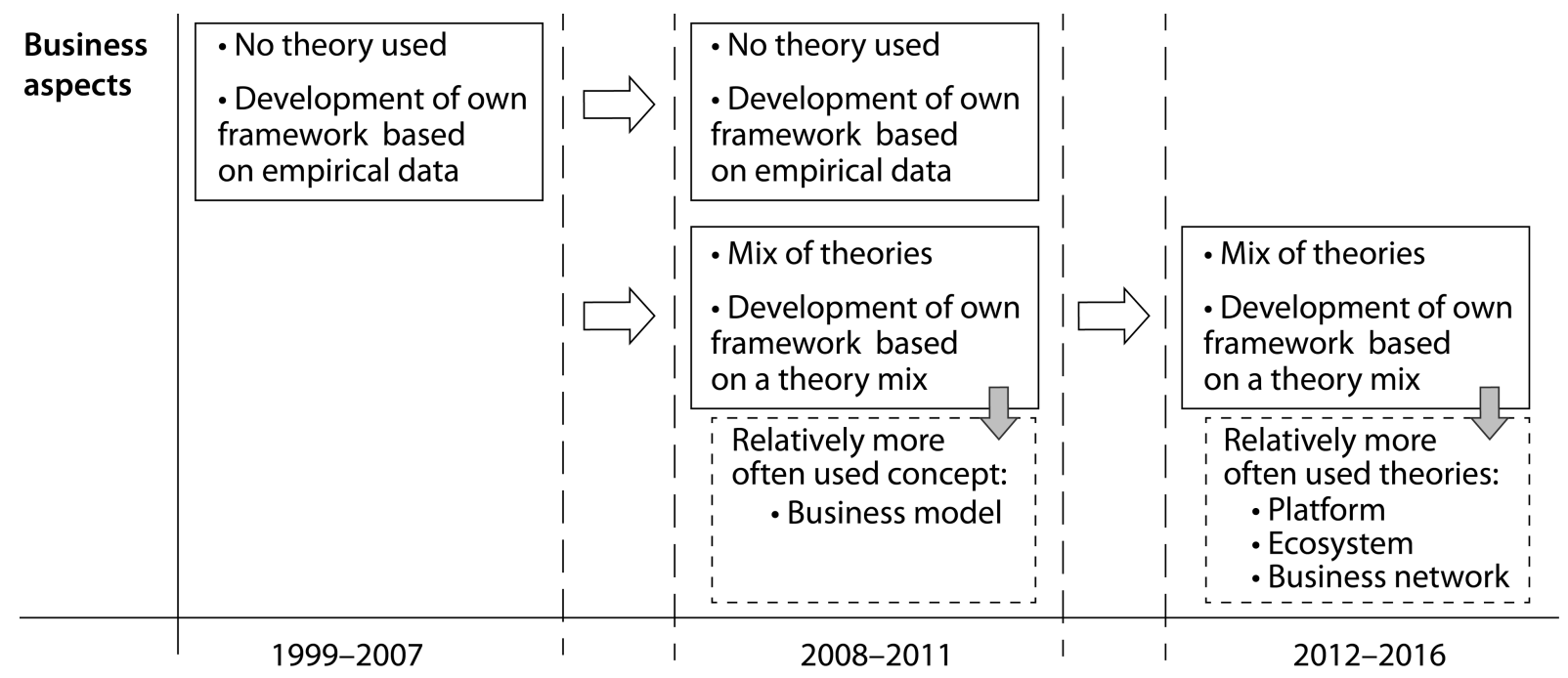

Fig. 9. Dynamic of theoretical base evolution within business aspects theme.

Summing up, the dynamics of theoretical base evolution in studies on business aspects demonstrate certain theoretical issues faced by researchers. It looks challenging to find a suitable theoretical background that could address the complex analysis of business aspects of mobile payments. One of the recent trends to solve this issue is to use a multi-level approach based upon a set of theories that allows analysis of complex business relations. Another notable trend is that, since the beginning, the researchers exploring business aspects have been focused on the creation of frameworks that could be applied specifically for the purpose of analysis of mobile payments. However, the majority of the developed frameworks were used only once. Neverthe- 
less, it is possible to expect that the same two trends will continue for the future. These trends were also discussed by Dahlberg et al. (2015).

\subsection{Summary of findings}

The discussion of the most common research and methodological approaches in research on mobile payments is summarised in Table 19.

Table 19. Generalisation of the main trends in research strategy and methodology.

\begin{tabular}{llll}
\hline Dimension & Customer adoption & $\begin{array}{l}\text { Technological } \\
\text { aspects }\end{array}$ & Business aspects \\
\hline Research strategy & Analytical statistical & - & $\begin{array}{l}\text { Analytical conceptual } \\
\text { Empirical case studies }\end{array}$ \\
\hline Research methodology & Quantitative & - & Qualitative \\
\hline Research method & Survey & $\begin{array}{l}\text { Development of } \\
\text { systems and } \\
\text { algorithms }\end{array}$ & $\begin{array}{l}\text { Conceptual work Case } \\
\text { study Desktop analysis } \\
\text { Interviews }\end{array}$ \\
\hline
\end{tabular}

The generalisation shows that within each research theme there is a specific well-established approach that prevails in terms of selection of a research strategy, type of methodology, and methods. This might be related to the multidisciplinary nature of research in the mobile payments area, where researchers tend to use the dominant research strategy and methodology within each specific research tradition. However, despite clearly dominant research methods within each theme, researchers use a mix of different research methods to explore the research questions in a more comprehensive way; this may explain the lack of progress that Dahlberg et al. (2015) point out.

When studying Table 19 on methodological and theoretical approaches to research in this field, we get a clear picture of how differentiated the research actually is. This confirms the conclusions in the literature review by Dahlberg et al. (2015) and provides a deeper explanation of why is has been difficult to integrate and synthesise research results in this field. Our next task is therefore to provide a proposal for an integrative framework that may help move research efforts forward.

\section{Discussion}

This paper presents an extensive systematic review of academic literature on mobile payments published during 2006-2016. In this section, we discuss the research findings and add a proposal for a research framework that can serve as an umbrella to integrate and synthesise research in this field.

\subsection{Issue of definition and scope of mobile payments}

Apparent confusion regarding the definition of mobile payments is shown in Table 5. In some works, it is unclear what exactly authors consider when they refer to mobile payments, especially when the definition is lacking. This is the case in $46 \%$ of papers. At the same time, a large number of researchers try to develop their own definition or to change existing definitions; only a minority (about a quarter) uses existing definitions. This suggests that the field of mobile payments is characterised by high degrees of change and a large number of very diverse actors. This means that definitions are likely to change depending on technological development and/or the prime 
focus on different actors such as banks, payment service providers, Fintech, telecom operators, and so on. This has also been highlighted by some researchers (Dahlberg, 2015; Dahlberg et al., 2015; Oliveira et al., 2016). It can also be expected that this lack of a shared definition will continue as research extends the scope and explores other use cases than PoS payments and transport ticketing.

It needs to be mentioned that Dahlberg, Mallat, et al. (2008, p. 166) contributed a lot to clarifying what mobile payment is by additionally stating that a mobile payment can be performed with "a mobile payment instrument such as a mobile credit card or a mobile wallet." This distinguished mobile payments from "any specific type of electronic or mobile money, the use of mobile devices to access electronic payment services, and electronic banking (unless there was a separate mobile payment 'instrument', or an account reserved for mobile payments)" (Dahlberg et al., 2015, p. 265). We adhere to that definition.

\subsection{Research themes}

In the current research, classification of papers by the major research themes has shown that studies on customer adoption and technology remain dominant in academic research (see Table 20). Another notable trend is a considerable increase in the number of studies on business aspects compared to the period 1998-2006. The same trends were noted by Dahlberg et al. (2015). However, it is possible to claim that, despite the fact that researchers have broadened their scope, the research focus remains rather narrow and fragmented. A number of other themes remain unaddressed. This is in line with the conclusions of Dahlberg et al. (2015).

Table 20. Comparison of trends in number of papers within the main research themes.

\begin{tabular}{lccc}
\hline Theme & $\begin{array}{c}\text { Dahlberg, Mallat, } \\
\text { et al. (2008a) } \\
\mathbf{1 9 9 8 - 2 0 0 6}\end{array}$ & $\begin{array}{c}\text { Dahlberg et al. } \\
(\mathbf{2 0 1 5}) \\
\mathbf{2 0 0 7 - 2 0 1 4}\end{array}$ & $\begin{array}{c}\text { The current } \\
\text { research } \\
\mathbf{2 0 0 7 - 2 0 1 6}\end{array}$ \\
\hline Customer adoption & 20 & 34 & 53 \\
\hline Technological aspects & 29 & 25 & 48 \\
\hline Business aspects & 5 & 20 & 32 \\
\hline
\end{tabular}

\subsection{Research focus}

Generalisation of the research focus and research questions (see Fig. 10) shows that:

- Customer adoption studies are focused on investigating service and customer characteristics and external factors that affect the process of mobile payments adoption.

- Studies on technological aspects are focused on the development of new service algorithms, protocols and systems, and their characteristics (security, privacy, interoperability, etc.).

- Studies on business aspects include analysis of business models, ecosystems, and external environmental factors. 


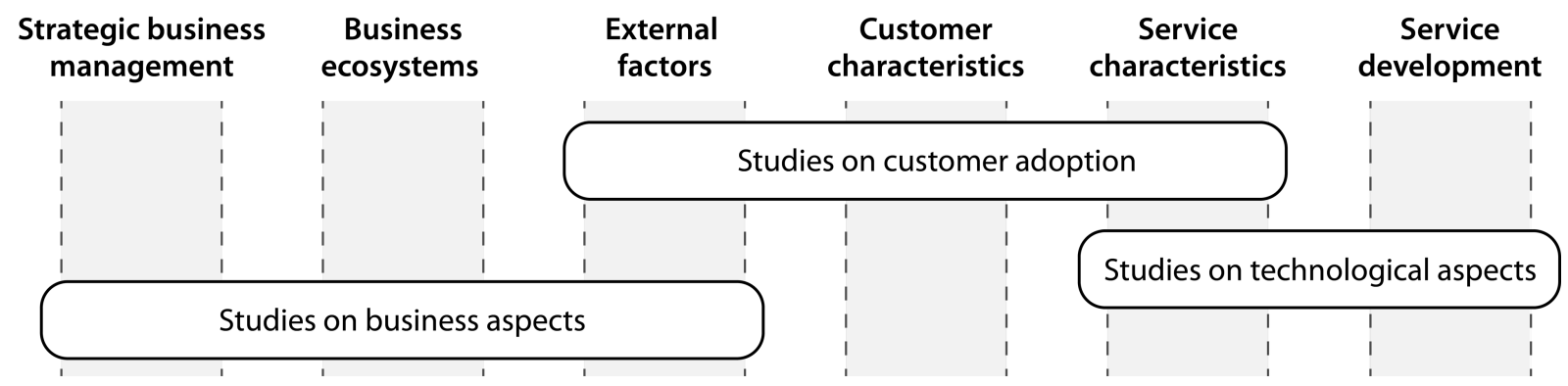

Fig. 10. Research focus and the main themes of mobile payments research.

The generalised scheme of research focus (Fig. 10) illustrates the fragmentation of research and its rather narrow focus. This finding is in line with the findings of Dahlberg et al. (2015).

\subsection{A proposal for an integrative research framework}

It is clearly shown in our review that theoretical and methodological approaches to research on mobile payments are highly diverse and difficult to integrate, which is in line with the conclusions by Dahlberg et al. (2015). Our conclusion from these findings is that we need a research framework than can integrate these diverse research approaches. There is a need to integrate research that differs in terms of theoretical approaches, selection of methodologies, definitions of units of analysis, and themes or focuses. Our proposal is to connect our field of research to more general theoretical frameworks on industrial transformation in socio-technical systems.

We pose the question of whether the socio-technical system approach may be used to develop our understanding of research on payments. We will now develop these ideas further in connection to the literature review done in this paper.

Theories on socio-technical systems were introduced to enable analysis of how a combination of social and technological factors explains innovation in and transformation of industries (Emery and Trist, 1965). However, over time, these theories have evolved to analyse large technical systems such as energy systems (Hughes, 1983, 1987) and, more recently, multi-level perspectives on transformation (Geels, 2004; Rip and Kemp, 1998). The multi-level perspective theory adds three aspects that make it particularly suitable for studies of mobile payment services and transformations of the payments industry. Firstly, it acknowledges parallel development patterns in different parts of the system, such as the landscape, the technological regime, and niches (Geels, 2004). These different levels make it possible to include landscape factors such as policies and regulations, technological regime factors such as card payment services and systems, and niche-related change factors such as mobile technologies and Fintech entrepreneurs all in the same model, even if a particular research project may and perhaps should delimit itself. Secondly, it puts a particular focus on the interplay between factors that conserve the status quo and those that stimulate radical transformation. Thirdly, it acknowledges both supply-driven aspects related to providers and demand-driven aspects related to users.

Geels' multi-level perspective model (2004, p. 915) highlights three different but mutually interdependent layers where change can be driven or be inhibited depending on each layer's characteristics. The outer layer is called the landscape and incorporates rules and institutions - such as regulative, normative, and cognitive (Scott, 1995) - that aim to coordinate and govern action in the system (Geels, 2004, p. 905). The middle layer is called the socio-technical regime. This is the most important part since this is where technologies, science, users and markets, socio-cultural aspects, and policies meet. These five dimensions serve to coordinate actions and 
interactions in the system (Geels, 2004, p. 906). These two layers then incorporate critical dimensions in a system such as the payment system. The third, inner part of the model is called technological niches and enables the analysis to incorporate factors related to radical innovation and transformation of the entire foundation of a system (Geels, 2004, p. 912).

Our choice of deploying the multi-level perspective (Geels, 2004) is motivated by the basic characteristics of the payment industry. Payment services have characteristics such as strong regulation and supervision by the state in the form of a policy regime; particular technological regimes related to different types of payment service; a clearly defined and important user and market regime in terms of both payees and payers; a strong and important socio-cultural regime related to the view of money and innovation; and a science regime related to research and development connected to digitalisation, Fintech, and payments.

Using Geels' model (2004, p. 915), we can now link it to identified research themes. We illustrate use of the model by using the main findings related to methodological approaches and theories (see Tables 18 and 19). This is presented in Table 21.

We can draw several conclusions from Table 21. Firstly, there is a lack of studies that incorporate all layers in a socio-technical system approach. Despite the fact that we used only a limited set of business papers from Table 18 to illustrate the model, the remaining papers can be associated with only one of the layers.

Secondly, there is a clear dominance of research in the middle layer - the socio-technical regime - to the detriment of the other two layers (i.e. the landscape and technological niches). Indeed, all papers on customer adoption and the majority of papers on technological aspects, with few exceptions (Ghiron et al., 2009; Pasquet et al., 2008; Rodrigues et al., 2014), are related to the middle level. The three mentioned papers are focused on experimental projects in niche markets.

Thirdly, there is a lack of research on two regimes of the middle layer. These are policy and socio-cultural aspects.

Summing up, the socio-technical system approach offers an integrative research framework that helps to synthesise the current state of the art in the research on mobile payments. It illustrates the fragmentation of research and points to the areas that require future research: there is a lack of research at the level of the landscape and technological niches, and a lack of papers on some socio-technical regimes. Studies in these directions would widen the research scope and the number of research themes and would help to overcome the problem of the existing research fragmentation. Additionally, we suggest that future research projects should consider different layers of the socio-technical system. This approach would provide a more holistic research picture and would contribute to a better integration of research findings in the area of mobile payments. 
Table 21. A multi-level perspective on the research on mobile payments.

\begin{tabular}{|c|c|c|}
\hline Layer & Dimension & Research themes/Research articles \\
\hline Landscape & Rules and institutions & - \\
\hline \multirow[t]{5}{*}{ Socio-technical regime } & Technology & $\begin{array}{l}\text { - Technological aspects Focus on service } \\
\text { development, technical standards }\end{array}$ \\
\hline & User and market & $\begin{array}{l}\text { - Customer adoption - Business aspects, e.g.: } \\
\text { Co-opetition (Andersson et al., 2013); Digital } \\
\text { payment framework (Kazan and Damsgaard, } \\
\text { 2013); NFC ecosystem model (Ok et al., 2013); } \\
\text { Discontinuance of collective action (de Reuver } \\
\text { et al., 2015); Market (non)emergence at the } \\
\text { convergence of distinct industries (Ozcan and } \\
\text { Santos, 2015); Service business model canvas } \\
\text { (Zolnowski et al., 2014); The mobile payment } \\
\text { market cooperation (MPMC) framework } \\
\text { (Hedman and Henningsson, 2015); A decision } \\
\text { model for platform openness (Ondrus et al., } \\
\text { 2015); Partnership management canvas } \\
\text { (Dennehy et al., 2015); Investment decision } \\
\text { model (Kauffman et al., 2015); Entry and } \\
\text { expansion strategy framework (Staykova and } \\
\text { Damsgaard, 2015); RISE model explaining how } \\
\text { initiators create payment platform ecosystem } \\
\text { (Zhong and Nieminen, 2015); StReS model to } \\
\text { analyse the business ecosystem on three levels: } \\
\text { structure, resources, and strategy (Guo and } \\
\text { Bouwman, 2016) }\end{array}$ \\
\hline & Science & Literature reviews \\
\hline & Socio-cultural aspects & - \\
\hline & Policy & - \\
\hline $\begin{array}{l}\text { Technological } \\
\text { niches }\end{array}$ & $\begin{array}{l}\text { Radical innovation in } \\
\text { niches }\end{array}$ & $\begin{array}{l}\text { - Technological aspects } \\
\text { Focus on development of radical innovation, } \\
\text { experimental projects in small niche markets } \\
\text { - Business aspects, e.g.: } \\
\text { A robust framework for the analysis of } \\
\text { economic issues for disruptive technologies (Au } \\
\text { and Kauffman, 2008) }\end{array}$ \\
\hline
\end{tabular}

\section{Conclusions}

This study was focused on the analysis of methodological and theoretical issues in research on mobile payments in the period during 2007-2016. The research dimensions included research strategy, discipline base, type of research, methodology used and methods, and theoretical perspective.

Based on the literature reviewed, it is possible to identify some principal characteristics. Research on mobile payments is a multidisciplinary research that is mainly focused on the three main themes: customer adoption, and technological and business aspects. The research strategy, methodology, and methods are specific within each of the main themes and are closely related 
to the dominant discipline base. The research focus within the main themes remains narrow. Dahlberg, Mallat, et al. (2008) and Dahlberg et al. (2015) contributed with an elaborated list of unaddressed research questions and directions for future research.

Current research on mobile payments lacks a systematic approach and the slow progress of the field is likely to be explained by a multitude of focused studies that are difficult to relate to each other and to the overall understanding of the industrial system for mobile payments. We therefore used a socio-technical system approach to introduce a perspective that may shed light on the ecosystem, a challenge identified by Dahlberg et al. (2015). By deploying a socio-technical, multi-level perspective (Geels, 2004), we were able to categorise the research identified in our literature review in a new way with the ambition of laying the foundation for future projects aiming to integrate and synthesise research findings in this area.

It is possible to specify major limitations of the contemporary research on mobile payments. As mentioned, one of the major limitations is the research fragmentation: (i) in terms of addressed themes (only three have been dominant during 1999-2016); (ii) in terms of discipline bases; and (iii) in terms of the research focus within each theme that is fragmented and narrow. We therefore propose a socio-technical, multi-level perspective to overcome these shortcomings.

The first contribution of this research is an in-depth investigation of methodological and theoretical aspects of research on mobile payments to show the dynamics and evolution of methodological approaches and theoretical perspectives. This also helps to estimate possible future trends in the mobile payments research area. A second contribution is a proposal for an integrative research framework that can help the field to overcome some of the problems pointed out in other studies.

To sum up, the most common research and methodological approaches are related to customer adoption, technologies and business, and are based on a large variety of methodologies. This has led to too narrowly focused research projects and a lack of integration and synthesis, which in the end has harmed scientific progress in the field. Our proposal to overcome these problems is to establish a foundation that may allow integration and synthesis; we therefore propose a socio-technical framework as this potential foundation. This framework may enable the research community to address the system-oriented challenge proposed by Dahlberg et al. (2015).

\section{References}

Adams, J., Khan, H.T.A., Raeside, R., \& White, D. (2007). Research Methods for Graduate Business and Social Science Students. New Delhi: Response Books.

Andersson, P., Markendahl, J., Mattsson, L.G., \& Rosenqvist, C. (2013). Cooperation and competition during evolution of technology based service innovation - The case of development of NFC enabled mobile services in Nice. Proceedings of the 12th International Conference on Mobile Business (ICMB), Berlin, 10.-13.06.2013. http://aisel.aisnet.org/icmb2013/7

Au, Y.A., \& Kauffman, R.J. (2008). The economics of mobile payments: Understanding stakeholder issues for an emerging financial technology application. Electronic Commerce Research and Applications, 7(2), 141-164.

Brakewood, C., Rojas, F., Robin, J., Sion, J., \& Jordan, S. (2014). Forecasting mobile ticketing adoption on commuter rail. Journal of Public Transportation, 17(1), 1-19.

Burgess, K., Singh, P.J., \& Koroglu, R. (2006). Supply chain management: A structured lit- 
erature review and implications for future research. International Journal of Operations and Production Management, 26(6), 703-729.

Carton, F., Hedman, J., Dennehy, D., Damsgaard, J., Tan, K.T., \& McCarthy, J.B. (2012). Framework for mobile payments integration. The Electronic Journal Information Systems Evaluation, 15(1), 14-25.

Cheng, Y.H., \& Huang, T.Y. (2013). High speed rail passengers' mobile ticketing adoption. Transportation Research Part C: Emerging Technologies, 30, 143-160.

Cocosila, M., \& Trabelsi, H. (2016). An integrated value-risk investigation of contactless mobile payments adoption. Electronic Commerce Research and Applications, 20, 159-170.

Dahlberg, T. (2015). Mobile payments in the light of money theories - Means to accelerate mobile payment services acceptance? Proceedings of the 17th International Conference on Electronic Commerce (ICEC), Seoul, 3.-5.08.2015. https://dl.acm.org/citation.cfm?id=2781584

Dahlberg, T., Huurros, M., \& Ainamo, A. (2008). Lost opportunity - Why has dominant design failed to emerge for the mobile payment services market in Finland? Proceedings of the 41st Hawaii International Conference on System Sciences (HICSS), Waikoloa, 7.-10.01.2008. http://ieeexplore.ieee.org/document/4438786/

Dahlberg, T., Mallat, N., Ondrus, J., \& Zmijewska, A. (2008). Past, present and future of mobile payments research: A literature review. Electronic Commerce Research and Applications, 7(2), $165-181$.

Dahlberg, T., Guo, J., \& Ondrus, J. (2015). A critical review of mobile payment research. Electronic Commerce Research and Applications, 14 (5), 265-284.

Dahlberg, T., \& Öörni, A. (2007). Understanding changes in consumer payment habits - Do mobile payments and electronic invoices attract consumers? Proceedings of the 40th Hawaii International Conference on System Science (HICSS), Waikoloa, 3.-6.01.2007. http://ieeexplore.ieee.org/document/407

de Albuquerque, J.P., Diniz, E.H., \& Cernev, A.K. (2016). Mobile payments: A scoping study of the literature and issues for future research. Information Development, 32(3), 527-553.

de Kerviler, G., Demoulin, N.T.M., \& Zidda, P. (2016). Adoption of in-store mobile payment: Are perceived risk and convenience the only drivers? Journal of Retailing and Consumer Services, 31, 334-344.

Dennehy, D., Adam, F., \& Carton, F. (2015). Mobile payment value networks: Designing a collaboration tool to approach key partnership issues. International Journal of Business Excellence, 8(4), 396-416.

Dennehy, D., \& Sammon, D. (2015). Trends in mobile payment research: A literature review. Journal of Innovation Management, 3(1), 49-61.

de Reuver, M., Verschuur, G., Nikayin, F., Cerpa, N., \& Bouwman, H. (2015). Collective action for mobile payment platforms: A case study on collaboration issues between banks and telecom operators. Electronic Commerce Research and Applications, 14 (5), 331-334.

Emery, F., \& Trist, E. (1965). The causal texture of organizational environments. Human Relations, 18, 21-32.

Gannamaneni, A., Ondrus, J., \& Lyytinen, K. (2015). A post-failure analysis of mobile payment platforms. Proceedings of the 48th Hawaii International Conference on System Sciences (HICSS), Kauai, 5.-8.01.2015. http://ieeexplore.ieee.org/abstract/document/7069948/ 
F.W. (2004). From sectoral systems of innovation to socio-technical systems: Insights about dynamics and change from sociology and institutional theory. Research Policy,33,897-920.

Ghiron, S., Sposato, S., Medaglia, C., \& Moroni, A. (2009). NFC ticketing: A prototype and usability test of an NFC-based virtual ticketing application. Proceedings of the First International Workshop on Near Field Communication (NFC), Hagenberg, 24.02.2009, 45-50. http://ieeexplore.ieee.org.focus.

Guo, J., \& Bouwman, H. (2016). An ecosystem view on third party mobile payment providers: A case study of Allipay wallet. Info, 18(5), 56-78.

Hedman, J., \& Henningsson, S. (2012). Competition and collaboration shaping the digital payment infrastructure. Proceedings of the 14th Annual International Conference on Electronic Commerce (ICEC), Singapore, 7.-8.08.2012, 178-185. https://dl.acm.org/citation.cfm?id=2346571

Hedman, J., \& Henningsson, S. (2015). The new normal: Market cooperation in the mobile payment ecosystem. Electronic Commerce Research and Applications, 14 (5), 305-318.

Hughes, T.P. (1983). Networks of Power: Electrification in Western Society, 1880-1930. Baltimore, MD: John Hopkins University Press.

Hughes, T.P. (1987). The Evolution of Large Technical Systems. In: W.E. Bijker, T.P. Hughes, \& T. Pinch (Eds.), The Social Construction of Technological Systems: New Directions in the Sociology and History of Technology, (pp. 51-82). Cambridge, MA: MIT Press.

Kauffman, R.J., Liu, J., \& Ma, D. (2015). Technology investment decision-making under uncertainty. Information Technology and Management, 16(2), 153-172.

Kazan, E., \& Damsgaard, J. (2013). A framework for analyzing digital payment as a multi-sided platform: A study of three European NFC solutions. Proceedings of the 21st European Conference on Information Systems (ECIS), Utrecht, 5-8.06.2013. http://aisel.aisnet.org/ecis2013_cr/133/

Kitchenham, B., \& Brereton, P. (2013). A systematic review of systematic review process research in software engineering. Information and Software Technology, 55(12), 2049-2075.

Kitchenham, B., Brereton, O.P., Budgen, D., Turner, M., Bailey, J., \& Linkman, S. (2009). Systematic literature reviews in software engineering - A systematic literature review. Information and Software Technology, 51(1), 7-15.

Liébana-Cabanillas, F., Sánchez-Fernández, J., \& Muñoz-Leiva, F. (2014a). Antecedents of the adoption of the new mobile payment systems: The moderating effect of age. Computers in Human Behavior, 35, 464-478.

Liébana-Cabanillas, F.J., Sánchez-Fernández, J., \& Muñoz-Leiva, F. (2014b). Role of gender on acceptance of mobile payment. Industrial Management 83 Data Systems, 114(2), 220-240.

Liébana-Cabanillas, F., Sánchez-Fernández, J., \& Muñoz-Leiva, F. (2014c). The moderating effect of experience in the adoption of mobile payment tools in virtual social networks: The m-payment acceptance model in virtual social networks (MPAM-VSN). International Journal of Information Management, 34(2), 151-166.

Liébana-Cabanillas, F., Muñoz-Leiva, F., \& Sánchez-Fernández, J. (2015). Behavioral model of younger users in m-payments systems. Journal of Organizational Computing and Electronic Commerce, 25(2), 169-190.

Liu, Y., Kostakos, V., \& Deng, S. (2013). Risks of using NFC mobile payment: Investigating the 
moderating effect of demographics attributes. Proceedings of the 15th International Conference on Electronic Commerce (ICEC), Turku, 13-15.08.2013, 125-134.

Morillo, F., Bordons, M., \& Gomez, I. (2003). Interdisciplinarity in science: A tentative typology of disciplines and research areas. Journal of the American Society for Information Science and Technology, 54 (13), 1237-1249.

Ok, K., Coskun, V., Ozdenizci, B., \& Aydin, M.N. (2013). A role-based service level NFC ecosystem model. Wireless Personal Communications, 68(3), 811-840.

Oliveira, T., Thomas, M., Baptista, G., \& Campos, F. (2016). Mobile payment: Understanding the determinants of customer adoption and intention to recommend the technology. Computers in Human Behavior, 61, 404-414.

Ondrus, J. (2015). Clashing over the NFC secure element for platform leadership in the mobile payment ecosystem. Proceedings of the 17th International Conference on Electronic Commerce (ICEC), Seoul, Article No. 30, 3.-5.08.2015. https://dl.acm.org/citation.cfm?id=2781598

Ondrus, J., Gannamaneni, A., \& Lyytinen, K. (2015). The impact of openness on the market potential of multi-sided platforms: A case study of mobile payment platforms. Journal of Information Technology, 30(3), 260-275.

Ondrus, J., \& Lyytinen, K. (2011). Mobile payments market: Towards another clash of the Titans? Proceedings of the 10th International Conference on Mobile Business (ICMB), Como, 17.10.2011, 166-172. http://ieeexplore.iee.org/abstract/document/6047067/

Ondrus, J., Lyytinen, K., \& Pigneur, Y. (2009). Why mobile payments fail? Towards a dynamic and multi-perspective explanation. Proceedings of the 42nd Hawaii International Conference on System Sciences (HICSS), Big Island, 5.-8.01.2009. http://ieeexplore.ieee.org/abstract/document/4755442/

Ozcan, P., \& Santos, F.M. (2015). The market that never was: Turf wars and failed alliances in mobile payments. Strategic Management Journal, 36(10), 1486-1512.

Pasquet, M., Reynaud, J., \& Rosenberger, C. (2008). Secure payment with NFC mobile phone in the SmartTouch project. Proceedings of the International Symposium on Collaborative Technologies and Systems (CTS), Irvine, 19.-23.05.2008, 121-126. http://ieeexplore.ieee.org.focus.lib.kth.se/document/4

Pousttchi, K. (2008). A modeling approach and reference models for the analysis of mobile payment use cases. Electronic Commerce Research and Applications, 7(2), 182-201.

Pousttchi, K., Schiessler, M., \& Wiedemann, D.G. (2009). Proposing a comprehensive framework for analysis and engineering of mobile payment business models. Information Systems and eBusiness Management, 7(3), 363-393.

Ramos-de-Luna, I., Montoro-Rios, F., \& Liébana-Cabanillas, F. (2016). Determinants of the intention to use NFC technology as a payment system: An acceptance model approach. Information Systems and e-Business Management, 14(2), 293-314.

Rip, A., \& Kemp, R. (1998). Technological Change. In: S. Rayner, \& E.L. Malone, (Eds.), Human Choice and Climate Change, (pp. 327-399). Columbus, OH: Battelle Press.

Rodrigues, H., Jose, R., Coelho, A., Melro, A., Ferreira, M.C., Cunha, J.F.E., Monteiro, M.P., \& Ribeiro, C. (2014). MobiPag: Integrated mobile payment, ticketing and couponing solution based on NFC. Sensors, $14(8), 13389-13415$.

Scott, W.R. (1995). Institutions and Organizations. London/New Delhi: Sage Publications. 
Slade, E.L., Williams, M.D., \& Dwivedi, Y.K. (2013). Mobile payment adoption: Classification and review of the extent literature. The Marketing Review, 13(2), 167-190.

Slade, E.L., Williams, M., Dwivedi, Y., \& Piercy, N. (2015b). Exploring consumer adoption of proximity mobile payments. Journal of Strategic Marketing, 23(3), 209-223.

Staykova, K.S., \& Damsgaard, J. (2015). The race to dominate the mobile payments platform: Entry and expansion strategies. Electronic Commerce Research and Applications, 14 (5), 319-330.

Taylor, E. (2016). Mobile payment technologies in retail: A review of potential benefits and risks. International Journal of Retail \& Distribution Management, 44(2), 159-177.

Van Bossuyt, M., \& Van Hove, L. (2007). Mobile payment models and their implications for NextGen MSPs. Info, 9(5), 31-43.

Viehland, D., \& Leong, R.S.Y. (2007). Acceptance and use of mobile payments. Proceedings of the 18th Australasian Conference on Information Systems (ACIS), Queensland, paper 16. https://aisel.aisnet.org/acis2007/16/

Wacker, J.G. (1998). A definition of theory: Research guidelines for different theory-building research methods in operations management. Journal of Operations Management, 16(4), 361385.

Woo, S.H., Pettit, S.J., Kwak, D.W., \& Beresford, A.K.C. (2011). Seaport research: A structured literature review on methodological issues since the 1980s. Transportation Research Part A: Policy and Practice, 45(7), 667-685.

Yang, Y.Q., Lui, Y., Li, H.X., \& Yu, B.H. (2015). Understanding perceived risks in mobile payment acceptance. Industrial Management \& Data Systems, 115(2), 311-331.

Zhong, J., \& Nieminen, M. (2015). Resource-based co-innovation through platform eco-system: Experiences of mobile payment innovation in China. Journal of Strategy and Management, 8(3), 283-298.

Zolnowski, A., Weis, C., \& Böhmann, T. (2014). Representing service business models with the service business model canvas - The case of a mobile payment service in the retail industry. Proceedings of the 47th Hawaii International Conference on System Sciences (HICSS), Waikoloa, 6.-9.01.2014, 718-727. http://ieeexplore.ieee.org/abstract/document/6758692/

\subsection{References (Included in literature review)}

\section{Papers on customer adoption}

Amoroso, D.L., \& Magnier-Watanabe, R. (2012). Building a research model for mobile wallet consumer sdoption: The case of mobile Suica in Japan. Journal of Theoretical and Applied Electronic Commerce Research, 7(1), 94-110.

Arvidsson, N. (2014). Consumer attitudes on mobile payment services - results from a proof of concept test. International Journal of Bank Marketing, 32(2), 150-170.

Augsburg, C., \& Hedman, J. (2014). Value added services and adoption of mobile payments. Proceedings of the 16th International Conference on Electronic Commerce (ICES), Philadelphia, 5.-6.08.2014. https://dl.acm.org/citation.cfm?id=2617851

Brakewood, C., Rojas, F., Robin, J., Sion, J., \& Jordan, S. (2014). Forecasting mobile ticketing adoption on commuter rail. Journal of Public Transportation, 17(1), 1-19. 
Chen, L.D. (2008). A model of consumer acceptance of mobile payment. International Journal of Mobile Communications, 6(1), 3252.

Cheng, Y.H., \& Huang, T.Y. (2013). High speed rail passengers' mobile ticketing adoption. Transportation Research Part C: Emerging Technologies, 30, 143-160.

Cocosila, M., \& Trabelsi, H. (2016). An integrated value-risk investigation of contactless mobile payments adoption. Electronic Commerce Research and Applications, 20, 159-170.

Dahlberg, T., \& Öörni, A. (2007). Understanding changes in consumer payment habits - Do mobile payments and electronic invoices attract consumers? Proceedings of the 40th Hawaii International Conference on System Science (HICSS), Waikoloa, 3.-6.01.2009. http://ieeexplore.ieee.org/abstract/docu

de Kerviler, G., Demoulin, N.T.M., \& Zidda, P. (2016). Adoption of in-store mobile payment: Are perceived risk and convenience the only drivers? Journal of Retailing and Consumer Services, 31, 334-344.

Di Pietro, L., Mugion, R.G., Mattia, G., Renzi, M.F., \& Toni, M. (2015). The integrated model on mobile payment acceptance (IMMPA): An empirical application to public transport. Transportation Research Part C: Emerging Technologies, 56, 463-479.

Duane, A., O'Reilly, P., \& Andreev, P. (2014). Realising m-payments: Modelling consumers willingness to m-pay using smart phones. Behaviour and Information Technology, 33(4), 318334.

Gerpott, T.J., \& Kornmeier, K. (2009). Determinants of customer acceptance of mobile payment systems. International Journal of Electronic Finance, 3(1), 1-30.

Goeke, L., \& Pousttchi, K. (2010). A scenario-based analysis of mobile payment acceptance. Proceedings of the Ninth International Conference on Mobile Business/Ninth Global Mobility Roundtable (ICMB-GMR), Athens, 13-15.06.2010, 371-378. http://ieeexplore.ieee.org/abstract/document/5494

Kim, C., Mirusmonov, M., \& Lee, I. (2010). An empirical examination of factors influencing the intention to use mobile payment. Computers in Human Behavior, 26 (3), 310-322.

Koenig-Lewis, N., Marquet, M., Palmer, A., \& Zhao, A.L. (2015). Enjoyment and social influence: Predicting mobile payment adoption. The Service Industries Journal, 35(10), 537554 .

Leong, L.Y., Hew, T.S., Tan, G.W.H., \& Ooi, K.B. (2013). Predicting the determinants of the NFC-enabled mobile credit card acceptance: A neural networks approach. Expert Systems with Applications, 40(14), 5604-5620.

Li, H., Liu, Y., \& Heikkilä, J. (2014). Understanding the factors driving NFC-enabled mobile payment adoption: an empirical investigation. Proceedings of the Pacific Asia Conference on Information Science (PACIS). https://aisel.aisnet.org/pacis2014/231/

Liébana-Cabanillas, F., Sánchez-Fernández, J., \& Muñoz-Leiva, F. (2014a). Antecedents of the adoption of the new mobile payment systems: The moderating effect of age. Computers in Human Behavior, 35, 464-478.

Liébana-Cabanillas, F.J., Sánchez-Fernández, J., \& Muñoz-Leiva, F. (2014b). Role of gender on acceptance of mobile payment. Industrial Management \& Data Systems, 114(2), 220-240.

Liébana-Cabanillas, F., Sánchez-Fernández, J., \& Muñoz-Leiva, F. (2014c). The moderating effect of experience in the adoption of mobile payment tools in virtual cocial networks: The 
m-payment acceptance model in virtual social networks (MPAM-VSN). International Journal of Information Management, 34(2), 151-166.

Liébana-Cabanillas, F., Muñoz-Leiva, F., \& Sánchez-Fernández, J. (2015). Behavioral model of younger users in m-payments systems. Journal of Organizational Computing and Electronic Commerce, 25(2), 169-190.

Liu, Y., Wang, S., \& Wang, X. (2011). A usability-centred perspective on intention to use mobile payment. International Journal of Mobile Communications, 9(6), 541-562.

Liu, Y., Kostakos, V., \& Deng, S. (2013). Risks of using NFC mobile payment: Investigating the moderating effect of demographics attributes. Proceedings of the 15th International Conference on Electronic Commerce (ICEC), Turku, 13-15.08.2013, 125-134.

Lu, Y., Yang, S., Chau, P.Y.K., \& Cao, Y. (2011). Dynamics between the trust transfer process and intention to use mobile payment services: A cross-environment perspective. Information $\&$ Management, 48(8), 393-403.

Mallat, M. (2007). Exploring consumer adoption of mobile payments - A qualitative study. Journal of Strategic Information Systems, 16(4), 413-432.

Mallat, N., Rossi, M., Tuunainen, V.K., \& Ö̈̈rni, A. (2009). The impact of use context on mobile services acceptance: The case of mobile ticketing. Information $\mathscr{E}$ Managemen, 46(3), 190-195.

Molina-Castillo, F.J., Rodriguez-Guirao, A., Lopez-Nicolas, C., \& Bouwman, H. (2016). Analysis of mobile pre-payment (pay in advance) and post-payment (pay later) services. International Journal of Mobile Communications, 14 (5), 499-517.

Moroni, A., Talamo, M., \& Dimitri, A. (2015). Adoption factors of NFC mobile payments in Italy. Proceedings of the 17th International Conference on Human-Computer Interaction with Mobile Devices and Services (Mobile HCI), Copenhagen, 24-27.08.2915, 393-399. https://dl.acm.org/citation.cfm?id=27

Morosan, C., \& DeFranco, A. (2016). It's about time: Revisiting UTAUT2 to examine consumers' intentions to use NFC mobile payments in hotels. International Journal of Hospitality Management, 53, 17-29.

Oliveira, T., Thomas, M., Baptista, G., \& Campos, F. (2016). Mobile payment: Understanding the determinants of customer adoption and intention to recommend the technology. Computers in Human Behavios, 61, 404-414.

O'Reilly, P., Duane, A., \& Andreev, P. (2012). To M-Pay or not to M-Pay - Realising the potential of smart phones: conceptual modeling and empirical validation. Electronic Markets, 22(4), 229-241.

Petrova, K. (2008). Mobile payment: Towards a customer-centric model. Proceedings of the Web Information Systems Engineering (WISE 2008 Workshops), in the series Lecture Notes in Computer Science (LNCS), 5176, 12-23.

Pham, T.T.T., \& Ho, J.C. (2015). The effects of product-related, personal-related factors and attractiveness of alternatives on consumer adoption of NFC-based mobile payments. Technology in Society, 43, 159-172.

Ramos-de-Luna, I., Montoro-Rios, F., \& Liébana-Cabanillas, F. (2016). Determinants of the intention to use NFC technology as a payment system: An acceptance model approach. Information Systems and e-Business Management, 14(2), 293-314. 
Schierz, P.G., Schilke, O., \& Wirtz, B.W. (2010). Understanding consumer acceptance of mobile payment services: An empirical analysis. Electronic Commerce Research and Applications, 9(3), 209-216.

Shaw, N. (2014). The mediating influence of trust in the adoption of the mobile wallet. Journal of Retailing and Consumer Service, 21(4), 449-459.

Shin, D.H. (2009). Towards an understanding of the consumer acceptance of mobile wallet. Computers in Human Behavior, 25 (6), 1343-1354.

Silic, M., Back, A., \& Ruf, C. (2014). Mobile contactless payments adoption challenge in the complex network actor ecosystem. Proceedings of the 27th Bled Electronic Commerce Conference, Bled, 1.-5.06.2014. https://aisel.aisnet.org/bled2014/33/

Slade, E.L., Dwivedi, Y.K., Piercy, N.C., \& Williams, M.D. (2015a). Modelling consumers' adoption intentions of remote mobile payments in the United Kingdom: Extending UTAUT with innovativeness, risk, and trust. Psychology 8 Marketing, 32(8), 860-873.

Slade, E.L., Williams, M., Dwivedi, Y., \& Piercy, N. (2015b). Exploring consumer adoption of proximity mobile payments. Journal of Strategic Marketing, 23(3), 209-223.

Tan, G.W.H., Ooi, K.B, Chong, S.C., \& Hew, T.S. (2014). NFC mobile credit card: The next frontier of mobile payment? Telematics and Informatics, 31(2), 292-307.

Teo, C.A., Tan, G.W.H., Ooi, K.B., Hew, T.S., \& Yew, K.T. (2015). The effects of convenience and speed in m-payments. Industrial Management and Data Systems, 115(2), 311-331.

Theodora, Z., Vaggelis, S., Maro, V., \& Rodoula, T. (2010). Predicting the adoption of mobile transactions: An exploratory investigation in Greece. Proceedings of the Ninth International Conference on Mobile Business/Ninth Global Mobility Roundtable (ICMB-GMR), Athens, 1315.06.2010, 141-147. http://ieeexplore.ieee.org/abstract/document/5494808/

Viehland, D., \& Leong, R.S.Y. (2007). Acceptance and use of mobile payments. Proceedings of the 18th Australasian Conference on Information Systems (ACIS), Queensland, paper 16. https://aisel.aisnet.org/acis2007/16/

Xin, H., Techatassanasoontorn, A.A., \& Tan, F.B. (2013). Exploring the influence of trust on mobile payment adoption. Proceedings of the Pacific Asia Conference on Information Science (PACIS), paper 143. https://aisel.aisnet.org/pacis2013/143/

Yang, S., Lu, Y., Gupta, S., Cao, Y., \& Zhang, R. (2012). Mobile payment services adoption across time: An empirical study of the effects of behavioral beliefs, social influences, and personal traits. Computers in Human Behavior, 28(1), 129-142.

Yang, Y.Q., Lui, Y., Li, H.X., \& Yu, B.H. (2015). Understanding perceived risks in mobile payment acceptance. Industrial Management and Data Systems, 115(2), 311-331.

Zhang, A., Yue, X., \& Kong, Y. (2011). Exploring culture factors affecting the adoption of mobile payment. Proceedings of the 10th International Conference on Mobile Business (ICMB), Como, 20.-21.06.2011, 263-267. http://ieeexplore.ieee.org/abstract/document/6047077/

Zhao, Y., \& Kurnia, S. (2014). Exploring mobile payment adoption in China. Proceedings of the Pacific Asia Conference on Information Science (PACIS), paper 232. https://aisel.aisnet.org/pacis2014/232/

Zhou, T. (2011). The effect of initial trust on user adoption of mobile payment. Information Development, 27(4), 290-300. 
Zhou, T. (2013). An empirical examination of continuance intention of mobile payment services. Decision Support Systems, 54(2), 1085-1091.

Zhou, T. (2014a). Understanding the determinants of mobile payment continuance usage. Industrial Management \& Data Systems, $114(6), 936-948$.

Zhou, T., 2014b. An empirical examination of initial trust in mobile payment. Wireless Personal Communications, 22(2), 1519-1531.

\section{Papers on technological aspects}

Ahamad, S.S., Sastry, V.N., \& Udgata, S.K. (2014). Secure mobile payment framework based on UICC with formal verification. International Journal of Computational Science and Engineering, $9(4), 355-370$.

Almuairfi, S., Veeraraghavan, P., Chilamkurti, N., \& Park, D.S. (2014). Anonymous proximity mobile payment (APMP). Peer-To-Peer Networking and Applicatons, 7(4), 620-627.

Ammayappan, K. (2015). TSM centric privacy preserving NFC mobile payment framework with formal verification. Proceedings of the Second International Conference on Electronics and Communication Systems (ICECS), Coimbatore, 26.-27.02.2015, 1490-1496. http://ieeexplore.ieee.org.focus.lib.kth.se

Basili, A., Liguori, W., Palumbo, F. (2014). NFC smart tourist card: Combining mobile and contactless technologies towards a smart tourist experience. Proceedings of the 23rd International WETICE Conference, Parma, 23.-25.06.2014, 249-254. http://ieeexplore.ieee.org.focus.lib.kth.se/document/69

Bottoni, A., \& Dini, G. (2007). Improving authentication of remote card transactions with mobile personal trusted devices. Computer Communications, 30(8), 1697-1712.

Clarke, R. (2008). A risk assessment framework for mobile payments. Proceedings of the 21st BLED eConference eCollaboration: Overcoming Boundaries Through Multi-Channel Interaction, Bled, 63-77. https://aisel.aisnet.org/bled2008/40/

Conti, V., Militello, C., Sorbello, F., \& Vitabile, S. (2009). A multimodal technique for an embedded fingerprint recognizer in mobile payment systems. Mobile Information Systems, 5(2), 105-124.

Fan, C.I., \& Huang, V.S.M. (2010). Provably secure integrated on/off-line electronic cash for flexible and efficient payment. IEEE Transactions on Systems Man Cybernetics Part c-Applications and Reviews, 40(5), 567-579.

Ferreira, M.C., Novoa, H., Dias, T.G., \& Cunha, J.F. (2014). A proposals for a public transport ticketing solution based on customers' mobile devices. The 16th Meeting of the Euro Working Group on Transportation, Porto, 2013. Procedia - Social and Behavioral Science, 111, 232241.

Fun, T.S., Beng, L.Y., Likoh, J., \& Roslan, R. (2008). A lightweight and private mobile payment protocol by using mobile network operator. Proceedings of the International Conference on Computer and Communication Engineering, Kuala Lumpur, 13.-15.05.2008, 162-166. http://ieeexplore.ieee.org.focus.lib.kth.se/document/4580588/

Ghiron, S., Sposato, S., Medaglia, C., \& Moroni, A. (2009). NFC ticketing: A prototype and usability test of an NFC-based virtual ticketing application. Proceedings of the First International Workshop on Near Field Communication (NFC), Hagenberg, 24.02.2009, 45-50. http://ieeexplore.ieee.org.focus.

Godbole, R.M., \& Pais, A.R. (2008). Secure and efficient protocol for mobile payments. Pro- 
ceedings of the 10th International Conference on Electronic Commerce (ICEC), Innsbruck, 19.22.08.2008. https://dl.acm.org/citation.cfm?id=1409574

Gold, K., Shetty, S., \& Rogers, T. (2015). A testbed for modelling and detecting attacks on NFC enabled mobile devices. Proceedings of the Military Communications Conference (MILCOM), Tampa, 26.-28.10.2015, 635-640. http://ieeexplore.ieee.org.focus.lib.kth.se/document/7357515/

Grønli, T.M., Pourghomi, P., \& Ghinea, G. (2015). Towards NFC payments using a lightweight architecture for the Web of Things. Computing, 97(10), 985-999.

Hassinen, M., Hyppönen, K., \& Trichina, E. (2008). Utilizing national public-key infrastructure in mobile payment systems. Electronic Commerce Research and Applications, 7(2), 214231.

Hwang, R.J., Shiau, S.H., \& Jan, D.F. (2007). A new mobile payment scheme for roaming services. Electronic Commerce Research and Applications, 6(2), 184-191.

Isaac, J.T., \& Zeadally, S. (2014). Design, implementation, and performance analysis of a secure payment protocol in a payment gateway centric model. Computing, 96(7), 587-611.

Isaac, J.T., Zeadally, S., \& Camara, J.S. (2012). A lightweight secure mobile payment protocol for vehicular ad-hoc networks (VANETs). Electronic Commerce Research, 12(1), 97-123.

Jiang, N., Liu, X.D., Zhao, J.Y., \& Yang, D.L. (2009). A mobile micropayment protocol based on Chaos. Proceedings of the Eighth International Conference on Mobile Business (ICMB), Dalian, 27.-28.06.2009, 284-289. http://ieeexplore.ieee.org.focus.lib.kth.se/document/5169273/

Kadambi, K.S., Li, J., \& Karp, A.H. (2009). Near-field communication-based secure mobile payment service. Proceedings of the 11th International Conference on Electronic Commerce (ICEC), Taopei, 12.-15.08.2009. https://dl.acm.org/citation.cfm?id=1593276

Konidala, D.M., Dwijaksara, M.H., Kim, K., Lee, D., Lee, B., Kim, D., \& Kim, S. (2012). Resuscitating privacy-preserving mobile payment with customer in complete control. Personal and Ubiquitous Computing, 16(6), 643-654.

Kousaridas, A., Parissis, G., \& Apostolopoulos, T. (2008). An open financial services architecture based on the use of intelligent mobile devices. Electronic Commerce Research and Applications, $7(2), 232-246$.

Kumar, S.B.R., \& Rabara, S.A. (2010). MPCS: Secure account-based mobile payment system. International Journal of Information Processing Management, 1(1), 59-69.

Lee, Y., Lee, J., \& Song, J. (2007). Design and implementation of wireless PKI technology suitable for mobile phone in mobile-commerce. Computer Communications, 30(4), 893-903.

Lei, Y.H., Quintero, A., \& Pierre, S. (2009). Mobile services access and payment through reusable tickets. Computer Communications, 32(4), 602-610.

Li, W., Wen, Q., Su, Q., \& Jin, Z. (2012). An efficient and secure mobile payment protocol for restricted connectivity scenarios in vehicular ad hoc network. Computer Communications, $35(2), 188-195$.

Lin, P., Chen, H.Y., Fang, Y., Jeng, J.Y., \& Lu, F.S. (2008). A secure mobile electronic payment architecture platform for wireless mobile networks. IEEE Transactions on Wireless Communications, 7(7), 2705-2713.

Luo, J.N., Yang M.H., \& Huang, S.Y. (2016). An unlinkable anonymous payment scheme based on near field communication. Computers and Electric Engineering, 49, 198-206. 
Martínez-Peláez, R., Toral-Cruz, H., Ruiz, J., \& Velarde-Alvarado, P. (2015). P2PM-pay: Person to person mobile payment scheme controlled by expiration date. Wireless Personal Communications, 85(1), 289-304.

Massoth, M., \& Bingel, T. (2009). Performance of different mobile payment service concepts compared with a NFC-based solution. Proceedings of the Fourth International Conference on Internet and Web Applications and Services (ICIW), Venice, 24.-28.05.2009, 205-210. http://ieeexplore.ieee.org.focus.lib.

Munch-Ellingsen, A., Karlsen, R., Andersen, A., \& Akselsen, S. (2015). Two-factor authentication for android host card emulated contactless cards. Proceedings of the First Conference on Mobile and Secure Services (MobiSecServ), Gainesville, 20.-21.02.2015, 1-6. http://ieeexplore.ieee.org.focus.lib.kth.

Ondrus, J., \& Pigneur, Y. (2009). Near field communication: An assessment for future payment systems. Information Systems and e-Business Management, 7(3), 347-361.

Ou, C.M., \& Ou C.R. (2009). Adaptation of proxy certificates to non-repudiation protocol of agent-based mobile payment systems. Applied Intelligence, 30(3), 233-243.

Pasquet, M., \& Gerbaix, S. (2016). Fraud on Host Card Emulation architecture. Proceedings of the Second International Conference on Mobile and Secure Services (MobiSecServ), Gainesville, 26-27.02.2016, 1-3. http://ieeexplore.ieee.org.focus.lib.kth.se/document/7440230/

Pasquet, M., Reynaud, J., \& Rosenberger, C. (2008). Secure payment with NFC mobile phone in the SmartTouch project. Proceedings of the International Symposium on Collaborative Technologies and Systems (CTS), Irvine, 19.-23.05.2008, 121-126. http://ieeexplore.ieee.org.focus.lib.kth.se/document/4

Popescu, C. (2009). An anonymous mobile payment system based on bilinear pairings. Informatica, 20(4), 579-590.

Rahimian, V., \& Habibi, J. (2008). MPaySmart: A customer centric approach in offering efficient mobile payment services. Proceedings of the Asia-Pacific Services Computing Conference (AP$S C C$ ), Yilan, 9.-12.12.2008, 1038-1043. http://ieeexplore.ieee.org.focus.lib.kth.se/document/4780815/

Rodrigues, H., Jose, R., Coelho, A., Melro, A., Ferreira, M.C., Cunha, J.F.E., Monteiro, M.P., \& Ribeiro, C. (2014). MobiPag: Integrated mobile payment, ticketing and couponing solution based on NFC. Sensors, 14(8), 13389-13415.

Sung, S., Youn, C., Kong, E., \& Ryou, J. (2015). User authentication using mobile phones for mobile payments. Proceedings of the International Conference on Information Networking (ICOIN), Cambodia, 12.-14.01.2015, 51-56. http://ieexplore.ieee.org.focus.lib.kth.se/document/7057856/

Veeraraghavan, P., Almuairfi, S., \& Chilamkurti, N. (2016). Anonymous paperless secure payment system using cloud. Journal of Supercomputing, 72(5), 1813-1824.

Wang, Y., Wong, D.S., \& Wang, H. (2008). Employ a mobile agent for making a payment. Mobile Information Systems, 4(1), 51-68.

Yang, D., Wang, H., Ren, Y., \& Wang, J. (2010). Mobile payment pattern based on multiple trusted platforms - China case. Proceedings of the Ninth International Conference on Mobile Business/Ninth Global Mobility Roundtable (ICMB-GMR), Athens, 13.-15.06.2010, 353-362. http://ieeexplore.ieee.org.focus.lib.kth.se/document/5494847/

Yang, J.H., \& Chang, C.C. (2012). A low computational-cost electronic payment scheme for mobile commerce with large-scale mobile users. Wireless Personal Communications, 63(1), 8399. 
Yang, J.H., \& Lin, P.Y. (2016). A mobile payment mechanism with anonymity for cloud computing. The Journal of Systems and Software, 116, 69-74.

Yang, M.H. (2014). Security enhanced EMV-based mobile payment protocol. Scientific World Journal, 2014, 1-19.

Zhang, G., Cheng, F., \& Meinel, C. (2008). SIMPA: A SIP-based mobile payment architecture. Proceedings of the Seventh International Conference on Computer and Information Science (ICIS), Portland, 14.-16.05.2008, 187-292. http://ieeexplore.ieee.org.focus.lib.kth.se/document/4529834/

Zhu, Y., \& Rice, J.E. (2009). A lightweight architecture for secure two-party mobile payment. Proceedings of the International Conference on Computational Science and Engineering (CSE), Vancouver, 29.-31.08.2009, 326-333. http://ieeexplore.ieee.org.focus.lib.kth.se/document/5284090/

Zhu, Y., Rice, J.E., Dobing, B., Shan, G., \& Dong, M. (2012). Feasibility evaluation of a secured architecture for 2-Party mobile payments (SA2pMP). Proceedings of the 11th International Conference on Computer and Information Science (ICIS), Shanghai, 30.05.-1.06.2012, 277-282. http://ieeexplore.ieee.org.focus.lib.kth.se/document/6211109/

\section{Papers on business aspects}

Andersson, P., Markendahl, J., Mattsson, L.G., \& Rosenqvist, C. (2013). Cooperation and competition during evolution of technology based service innovation - The case of development of NFC enabled mobile services in Nice. Proceedings of the 12th International Conference on Mobile Business (ICMB), Berlin, 10.-13.06.2013. http://aisel.aisnet.org/icmb2013/7

Apanasevic, T. (2013). Factors influencing the slow rate of penetration of NFC mobile payment in Western Europe. Proceedings of The 12th International Conference on Mobile Business (ICMB), Berlin, 10.-13.06.2013. https://aisel.aisnet.org/icmb2013/8/

Au, Y.A., \& Kauffman, R.J. (2008). The economics of mobile payments: Understanding stakeholder issues for an emerging financial technology application. Electronic Commerce Research and Applications, 7(2), 141-164.

Carton, F., Hedman, J., Dennehy, D., Damsgaard, J., Tan, K.T., \& McCarthy, J.B. (2012). Framework for mobile payments integration. The Electronic Journal Information Systems Evaluation, 15(1), 14-25.

Dahlberg, T., Huurros, M., Ainamo, A. (2008). Lost opportunity - Why has dominant design failed to emerge for the mobile payment services market in Finland? Proceedings of the 41st Hawaii International Conference on System Sciences (HICSS), Waikoloa, 7.-1-.01.2008. http://ieeexplore.ieee.org.focus.lib.kth.se/document/4438786/

Dennehy, D., Adam, F., \& Carton, F. (2015). Mobile payment value networks: Designing a collaboration tool to approach key partnership issues. International Journal of Business Excellence, $8(4), 396-416$.

de Reuver, M., Verschuur, G., Nikayin, F., Cerpa, N., \& Bouwman, H. (2015). Collective action for mobile payment platforms: A case study on collaboration issues between banks and telecom operators. Electronic Commerce Research and Applications, 14 (5), 331-334.

Gannamaneni, A., Ondrus, J., \& Lyytinen, K. (2015). A post-failure analysis of mobile payment platforms. Proceedings of the 48 th Hawaii International Conference on System Sciences (HICSS), Kauai, 5.-8.01.2015. http://ieeexplore.ieee.org.focus.lib.kth.se/document/7069948/

Gaur, A., \& Ondrus, J. (2012). The role of banks in the mobile payment ecosystem: A strategic 
asset perspective. Proceedings of the 14th Annual International Conference on Electronic Commerce (ICEC), Singapore, 7.-8.08.2012, 171-177. https://dl.acm.org/citation.cfm?id=2346570

Ghezzi, A., Renga, F., Balocco, R., \& Pescetto, P. (2010). Mobile payment applications: Offer state of the art in the Italian market. Info, 12(5), 3-22.

Guo, J., \& Bouwman, H. (2016b). An ecosystem view on third party mobile payment providers: A case study of Allipay wallet. Info, 18(5), 56-78.

Hedman, J., \& Henningsson, S. (2012). Competition and collaboration shaping the digital payment infrastructure. Proceedings of the 14th Annual International Conference on Electronic Commerce (ICEC), Singapore, 7.-8.08.2012, 178-185. https://dl.acm.org/citation.cfm?id=2346571

Hedman, J., \& Henningsson, S. (2015). The new normal: Market cooperation in the mobile payment ecosystem. Electronic Commerce Research and Applications, 14(5), 305-318.

Juntunen, A., Tuunainen, V.K., \& Luukkainen, S. (2012). Deploying NFC yechnology for mobile ticketing services - Identification of critical business model issues. International Journal of eServices and Mobile Applications, 4(3), 23-41.

Kanniainen, L. (2010). Alternatives for banks to offer secure mobile payments. International Journal of Bank Marketing, 28(5), 433-444.

Kauffman, R.J., Liu, J., \& Ma, D. (2015). Technology investment decision-making under uncertainty. Information Technology Management, 16(2), 153-172.

Kazan, E., \& Damsgaard, J. (2013). A framework for analyzing digital payment as a multi-sided platform: A study of three European NFC solutions. Proceedings of the 21st European Conference on Information Systems (ECIS), Utrecht. http://aisel.aisnet.org/ecis2013_cr/133/

Liu, J., Kauffman, R.J., \& Ma, D. (2015). Competition, cooperation, and regulation: Understanding the evolution of the mobile payments technology ecosystem. Electronic Commerce Research and Applications, $14(5), 372-391$.

Magnier-Watanabe, R. (2014). An institutional perspective of mobile payment adoption: The case of Japan. Proceedings of the 47th Hawaii International Conference on System Sciences (HICSS), Waikoloa, 6.-9.01.2014, 1043-1052. http://ieeexplore.ieee.org.focus.lib.kth.se/document/6758733/

Markendahl, J. (2013). Change of market structure for mobile payments services in Sweden The case of SMS tickets. Proceedings of the 12th International Conference on Mobile Business (ICMB), Berlin, 10.-13.06.2013. https://aisel.aisnet.org/icmb2013/23/

Ok, K., Coskun, V., Ozdenizci, B., \& Aydin, M.N. (2013). A role-based service level NFC ecosystem model. Wireless Personal Communications, 68(3), 811-840.

Ondrus, J. (2015). Clashing over the NFC secure element for platform leadership in the mobile payment ecosystem. Proceedings of the 17th International Conference on Electronic Commerce (ICEC), Seoul, Article No. 30. https://dl.acm.org/citation.cfm?id=2781598

Ondrus, J., Gannamaneni, A., \& Lyytinen, K. (2015). The impact of openness on the market potential of multi-sided platforms: A case study of mobile payment platforms. Journal of Information Technology, 30(3), 260-275.

Ondrus, J., \& Lyytinen, K. (2011). Mobile payments market: Towards another clash of the Titans? Proceedings of the 10th International Conference on Mobile Business (ICMB), Como, 17.10.2011, 166-172. http://ieeexplore.ieee.org/abstract/document/6047067/

Ondrus, J., Lyytinen, K., \& Pigneur, Y. (2009). Why mobile payments fail? Towards a dynamic 
and multi-perspective explanation. Proceedings of the 42nd Hawaii International Conference on System Sciences (HICSS), Big Island, 5.-8.01.2009. http://ieeexplore.ieee.org/abstract/document/4755442/

Ozcan, P., \& Santos, F.M. (2015). The market that never was: Turf wars and failed alliances in mobile payments. Strategic Management Journal, 36(10), 1486-1512.

Pousttchi, K. (2008). A modeling approach and reference models for the analysis of mobile payment use cases. Electronic Commerce Research and Applications, 7(2), 182-201.

Pousttchi, K., Schiessler, M., \& Wiedemann, D.G. (2009). Proposing a comprehensive framework for analysis and engineering of mobile payment business models. Information Systems and eBusiness Management, 7(3), 363-393.

Staykova, K.S., \& Damsgaard, J. (2015). The race to dominate the mobile payments platform: Entry and expansion strategies. Electronic Commerce Research and Applications, 14 (5), 319-330.

Van Bossuyt, M., \& Van Hove, L. (2007). Mobile payment models and their implications for NextGen MSPs. Info, 9(5), 31-43.

Zhong, J., \& Nieminen, M. (2015). Resource-based co-innovation through platform eco-system: Experiences of mobile payment innovation in China. Journal of Strategy and Management, 8(3), 283-298.

Zolnowski, A., Weis, C., \& Böhmann, T. (2014). Representing service business models with the service business model canvas - The case of a mobile payment service in the retail industry. Proceedings of the $4^{7}$ th Hawaii International Conference on System Sciences (HICSS), Waikoloa, 6.-9.01.2014, 718-727. http://ieeexplore.ieee.org.focus.lib.kth.se/document/6758692/

\section{Papers on law and regulation}

Kemp, R. (2013). Mobile payments: Current and emerging regulatory and contracting issues. Computer Law and Security Review, 29(2), 175-179.

Lim, A.S. (2008). Inter-consortia battles in mobile payments standardization. Electronic Commerce Research and Applications, 7(2), 202-213.

Liu, Y. (2015). Consumer protection in mobile payments in China: A critical analysis of Alipay's service agreement. Computer Law and Security Review, 31(5), 679-688.

Vandezande, N. (2014). Between Bitcoin and mobile payments: Will the European Commission's new proposal provide more legal certainty? International Journal of Law and Information Technology, 22, 295-310.

\section{Papers on merchant adoption}

Apanasevic, T., Markendahl, J., \& Arvidsson, N. (2016). Stakeholders' expectations of mobile payment in retail: Lessons from Sweden. International Journal of Bank Marketing, 34(1), 37-61.

Guo, J., \& Bouwman, H. (2016a). An analytical framework for an m-payment ecosystem: A merchants' perspective. Telecommunications Policy, 40(2-3), 147-167.

Mallat, N., \& Tuunainen, V.K. (2008). Exploring merchant adoption of mobile payment systems: An empirical study. e-Service Journal, 6(2), 24-57.

Wiechert, T., Thuesse, F., \& Fleisch, E. (2009). A quantitative evaluation of NFC based con- 
tactless payment system in retail. Proceedings of the 17th European Conference on Information Systems (ECIS), Verona, 8.-10.06.2009. https://aisel.aisnet.org/ecis2009/243/

\section{Papers on mobile payments}

Dahlberg, T. (2015). Mobile payments in the light of money theories - Means to accelerate mobile payment services acceptance? Proceedings of the 17th International Conference on Electronic Commerce (ICEC), Seoul, 3.-5.08.2015. https://dl.acm.org/citation.cfm?id=2781584

Hu, X., Li, W., \& Hu, Q. (2008). Are mobile payment and banking the killer apps for mobile commerce? Proceedings of the 41st Hawaii International Conference on System Sciences (HICSS), Waikoloa, 7.-10.01.2008. http://ieeexplore.ieee.org.focus.lib.kth.se/document/4438787/

Olsen, M., Hedman, J., \& Vatrapu, R. (2012). Designing digital payment artifacts. Proceedings of the 14th Annual International Conference on Electronic Commerce (ICEC), Singapore, 7.8.08.2012. https://dl.acm.org/citation.cfm?id=2346568

Zhong, J. (2009). A comparison of mobile payment procedures in Finnish and Chinese markets. Proceedings of the 22nd Bled eConference eEnablement - Facilitating an Open, Effective and Representative eSociety, Bled, 14.-17.06.2009, 79-96. https://aisel.aisnet.org/bled2009/37/

\section{Appendix A. Use cases and technologies addressed in research}

Table A.1. Mobile payment use cases discussed in selected papers.

\begin{tabular}{|c|c|c|c|c|c|c|c|}
\hline $\begin{array}{l}\text { Use case } \\
\text { (No. of papers) }\end{array}$ & $\begin{array}{l}\mathrm{CA}^{*} \\
(53)\end{array}$ & $\begin{array}{r}\text { TA } \\
(48) \\
\end{array}$ & $\begin{array}{r}\mathrm{BA} \\
(30) \\
\end{array}$ & $\begin{array}{l}\text { Law } \\
(4)\end{array}$ & $\begin{array}{l}\text { MA } \\
(4)\end{array}$ & $\begin{array}{l}\mathrm{MP} \\
(4)\end{array}$ & $\begin{array}{l}\text { Total } \\
(145)\end{array}$ \\
\hline $\begin{array}{l}\text { Mobile payments (use } \\
\text { case not specified) }\end{array}$ & 42 & 19 & 28 & 3 & 0 & 3 & 95 \\
\hline PoS mobile payment & 4 & 17 & 3 & 0 & 4 & 1 & 29 \\
\hline $\begin{array}{l}\text { Public transport } \\
\text { ticketing }\end{array}$ & 6 & 2 & 5 & 0 & 1 & 1 & 15 \\
\hline Parking fee payments & 1 & 0 & 1 & 0 & 0 & 0 & 2 \\
\hline Vending machines & 1 & 1 & 1 & 0 & 1 & 1 & 5 \\
\hline Mobile content & 0 & 0 & 1 & 0 & 0 & 1 & 2 \\
\hline $\begin{array}{l}\text { Purchases in online } \\
\text { shops }\end{array}$ & 1 & 2 & 1 & 0 & 0 & 1 & 5 \\
\hline Event ticketing & 0 & 0 & 1 & 0 & 0 & 0 & 1 \\
\hline $\mathrm{P} 2 \mathrm{P}$ & 0 & 1 & 3 & 0 & 0 & 0 & 4 \\
\hline $\begin{array}{l}\text { Vehicular ad-hoc } \\
\text { network, } \\
\text { vehicle-to-vehicle and } \\
\text { vehicle-to-roadside } \\
\text { communication }\end{array}$ & 0 & 2 & 0 & 0 & 0 & 0 & 2 \\
\hline
\end{tabular}

* CA: Customer adoption; TA: Technological aspects; BA: Business aspects; Law: Law and regulation; MA: Merchant adoption; MP: Mobile payments.

Table A.2. Mobile payment technologies discussed in selected papers. 


\begin{tabular}{|c|c|c|c|c|c|c|c|}
\hline Technology & $\begin{array}{c}\mathrm{CA}^{*} \\
\text { (23 out } \\
\text { of } 54 \\
\text { papers) }\end{array}$ & $\begin{array}{c}\text { TA } \\
\text { (34 out } \\
\text { of } 48 \\
\text { papers) }\end{array}$ & $\begin{array}{c}\text { BA } \\
(25 \text { out } \\
\text { of } 32 \\
\text { papers })\end{array}$ & $\begin{array}{c}\text { Law } \\
(3 \text { out of } \\
4 \text { papers })\end{array}$ & $\begin{array}{c}\text { MA } \\
\text { (1 out of } \\
4 \text { papers })\end{array}$ & $\begin{array}{c}\mathrm{MP} \\
(2 \text { out of } \\
4 \text { papers })\end{array}$ & $\begin{array}{c}\text { Total** } \\
\text { (88 out } \\
\text { of } 146 \\
\text { papers) }\end{array}$ \\
\hline $\mathrm{NFC}$ & 15 & 17 & 16 & 1 & 1 & 0 & 50 \\
\hline SMS & 7 & 2 & 9 & 2 & 0 & 1 & 21 \\
\hline $\begin{array}{l}\text { WAP/mobile } \\
\text { internet }\end{array}$ & 2 & 10 & 3 & 2 & 0 & 1 & 18 \\
\hline QR code & 2 & 0 & 0 & 1 & 0 & 0 & 3 \\
\hline Mobile networks & 0 & 5 & 0 & 3 & 0 & 0 & 8 \\
\hline Bluetooth & 1 & 2 & 0 & 1 & 0 & 0 & 4 \\
\hline UICC & 0 & 1 & 0 & 0 & 0 & 0 & 1 \\
\hline $\begin{array}{l}\text { Mobile payment } \\
\text { card terminals } \\
\text { (Square, iZettle) }\end{array}$ & 0 & 0 & 4 & 0 & 0 & 0 & 4 \\
\hline App based & 0 & 0 & 4 & 0 & 0 & 1 & 5 \\
\hline RFID & 0 & 0 & 0 & 1 & 0 & 0 & 1 \\
\hline
\end{tabular}

* CA: Customer adoption; TA: Technological aspects; BA: Business aspects; Law: Law and regulation; MA: Merchant adoption; MP: Mobile payments. ** The technology behind the mobile payment services is specified in $60 \%$ of papers (or in 88 out of 146 papers).

\section{Appendix B. Research methodology and methods}

Table B.1. Research methods used in studies on mobile payments' customer adoption.

\begin{tabular}{|c|c|c|}
\hline Methods & No. of papers & References \\
\hline Total No. of papers & 53 & \\
\hline $\begin{array}{l}\text { Conceptual work } \\
\text { (Theoretical discussion, } \\
\text { speculation, } \\
\text { theory-building) }\end{array}$ & 1 & Petrova, 2008 \\
\hline Desktop analysis & 1 & Silic et al., 2014 \\
\hline Interviews & 7 & $\begin{array}{l}\text { Arvidsson, 2014; Chen, 2008; Kim et al., 2010; } \\
\text { Moroni et al., 2015; Shin, 2009; Silic et al., } \\
\text { 2014; Zhao and Kurnia, } 2014\end{array}$ \\
\hline Focus groups & 3 & Di Pietro et al., 2015; Mallat, 2007; Shin, 2009 \\
\hline
\end{tabular}




\begin{tabular}{|c|c|c|}
\hline Methods & No. of papers & References \\
\hline Survey & 47 & $\begin{array}{l}\text { Arvidsson, 2014; Augsburg and Hedman, 2014; } \\
\text { Brakewood et al., 2014; Chen, 2008; Chen and } \\
\text { Huang, 2013; Cocosila and Trabelsi, 2016; } \\
\text { Dahlberg and Öörni, 2007; de Kerviler et al., } \\
\text { 2016; Di Pietro et al., 2015; Duane et al., 2014; } \\
\text { Gerpott and Kornmeier, 2009; Goeke and } \\
\text { Pousttchi, 2010; Kim et al., 2010; } \\
\text { Koening-Lewis et al., 2015; Leong et al., 2013; } \\
\text { Li et al., 2014; Liébana-Cabanillas et al., 2014a; } \\
\text { Liébana-Cabanillas et al., 2014b; } \\
\text { Liébana-Cabanillas et al., 2014c; } \\
\text { Liébana-Cabanillas et al., 2015; Liu et al., 2011; } \\
\text { Liu et al., 2013; Lu et al., 2011; Mallat et al., } \\
\text { 2009; Molina-Castillo et al., 2016; Morosan and } \\
\text { DeFranco, 2016; Moroni et al., 2015; Oliveira et } \\
\text { al., 2016; O'Reilly et al., 2014; Pham and Ho, } \\
\text { 2015; Ramos-de-Luna et al., 2016; Schierz et } \\
\text { al., 2010; Shaw, 2014; Shin, 2009; Slade et al., } \\
\text { 2015a; Slade et al., 2015b; Tan et al., 2014; Teo } \\
\text { et al., 2015; Theodora et al., 2010; Viehland } \\
\text { and Leong, 2007; Xin et al., 2013; Yang et al., } \\
\text { 2012; Yang et al., 2015; Zhou, 2011; Zhou, } \\
\text { 2013; Zhou, 2014a; Zhou, 2014b }\end{array}$ \\
\hline Case study & 3 & $\begin{array}{l}\text { Amoroso and Magnier-Watanabe, } 2012 \\
\text { Petrova, 2008; Silic et al., } 2014\end{array}$ \\
\hline $\begin{array}{l}\text { Development of systems and } \\
\text { algorithms }\end{array}$ & 0 & \\
\hline Mathematical modeling & 0 & \\
\hline Experiment/ simulation & 5 & $\begin{array}{l}\text { Liébana-Cabanillas et al., 2014a; } \\
\text { Liébana-Cabanillas et al., 2014b; } \\
\text { Liébana-Cabanillas et al., 2014c; } \\
\text { Liébana-Cabanillas et al., 2015; } \\
\text { Ramos-de-Luna et al., 2016 }\end{array}$ \\
\hline Prototype & 0 & \\
\hline Usability test & 0 & \\
\hline Empirical test & 3 & Moroni et al., 2015; Zhou, 2011; Zhou, 2014b \\
\hline Proof of concept & 0 & \\
\hline
\end{tabular}

Table B.2. Research methods used in studies on mobile payments technology aspects.

\begin{tabular}{lcl}
\hline Methods & No. of papers & References \\
\hline Total No. of papers & 48 & \\
\hline $\begin{array}{l}\text { Conceptual work } \\
\text { (Theoretical discussion, }\end{array}$ & 3 & $\begin{array}{l}\text { Basili et al., 2014; Clarke, 2008; Pasquet and } \\
\text { Gerbaix, 2016 }\end{array}$ \\
$\begin{array}{l}\text { speculation, } \\
\text { theory-building) }\end{array}$ & & \\
\hline Desktop analysis & 0 & \\
\hline
\end{tabular}




\begin{tabular}{|c|c|c|}
\hline Methods & No. of papers & References \\
\hline Interviews & 2 & $\begin{array}{l}\text { Ondrus and Pigneur, 2009; Rodrigues et al., } \\
2014\end{array}$ \\
\hline Focus groups & 0 & \\
\hline Survey & 1 & Rodrigues et al., 2014 \\
\hline Case study & 0 & \\
\hline $\begin{array}{l}\text { Development of systems and } \\
\text { algorithms }\end{array}$ & 43 & $\begin{array}{l}\text { Ahamad et al., 2014; Almuairfi et al., 2014; } \\
\text { Ammayappan, 2015; Bottoni and Deni, 2007; } \\
\text { Clarke, 2008; Conti et al., 2009; Fan and } \\
\text { Huang, 2010; Fun et al., 2008; Ghiron et al., } \\
\text { 2009; Godbole and Pais, 2008; Gold et al., } \\
\text { 2015; Grønli et al., 2015; Hassinen et al., 2008; } \\
\text { Hwang et al., 2007; Isaac and Zeadally, 2014; } \\
\text { Isaac et al., 2012; Jiang et al., 2009; Kadambi } \\
\text { et al., 2009; Konidala et al., 2012; Kousaridas } \\
\text { et al., 2008; Kumar and Rabara, 2010; Lee et } \\
\text { al., 2007; Lei et al., 2009; Li et al., 2012; Lin et } \\
\text { al., 2008; Luo et al., 2016; Martínez-Peláez et } \\
\text { al., 2015; Massoth and Bingel, 2009; } \\
\text { Munch-Ellingsen et al., 2015; Ou and Ou, 2009; } \\
\text { Pasquet et al., 2008; Popescu, 2009; Rahimian } \\
\text { and Habibi, 2008; Rodrigues et al., 2014; Sung } \\
\text { et al., 2015; Veeraraghavan, et al., 2016; Wang } \\
\text { et al., 2008; Yang, 2014; Yang and Chang, } \\
\text { 2012; Yang and Lin, 2016; Zhang et al., 2008; } \\
\text { Zhu and Rice, 2009; Zhu et al., 2012 }\end{array}$ \\
\hline Mathematical modeling & 0 & \\
\hline Experiment/simulation & 10 & $\begin{array}{l}\text { Ammayappan, 2015; Bottoni and Deni, 2007; } \\
\text { Godbole and Pais, 2008; Isaac et al., 2012; Lee } \\
\text { et al., 2007; Lei et al., 2009; Ondrus and } \\
\text { Pigneur, 2009; Yang, 2014; Zhu and Rice, 2009; } \\
\text { Zhu et al., 2012 }\end{array}$ \\
\hline Prototype & 18 & $\begin{array}{l}\text { Ahamad et al., 2014; Bottoni and Deni, 2007; } \\
\text { Conti et al., 2009; Ferreira et al., 2009; Ghiron } \\
\text { et al., 2009; Hassinen et al., 2008; Isaac and } \\
\text { Zeadally, 2014; Isaac et al., 2012; Kadambi et } \\
\text { al., 2009; Konidala et al., 2012; Kousaridas et } \\
\text { al., 2008; Lee et al., 2007; Massoth and Bingel, } \\
\text { 2009; Munch-Ellingsen et al., 2015; Pasquet et } \\
\text { al., 2008; Rahimian and Habibi, 2008; } \\
\text { Rodrigues et al., 2014; Zhang et al., } 2008\end{array}$ \\
\hline Usability test & 6 & $\begin{array}{l}\text { Ferreira et al., 2009; Ghiron et al., 2009; Isaac } \\
\text { et al., 2012; Massoth and Bingel, 2009; } \\
\text { Rahimian and Habibi, 2008; Rodrigues et al., } \\
2014\end{array}$ \\
\hline Empirical test & 0 & \\
\hline Proof of concept & 0 & \\
\hline
\end{tabular}

Table B.3. Research methods used in studies on mobile payments' business aspects. 


\begin{tabular}{|c|c|c|}
\hline Methods & No. of papers & References \\
\hline Total No. of papers & 32 & \\
\hline $\begin{array}{l}\text { Conceptual work } \\
\text { (Theoretical discussion, } \\
\text { speculation, } \\
\text { theory-building) }\end{array}$ & 25 & $\begin{array}{l}\text { Andersson et al., 2013; Au and Kauffman, } \\
\text { 2008; Carton et al., 2012; Dahlberg, Huurros, } \\
\text { et al., 2008; Dennehy et al., 2015; de Reuver et } \\
\text { al., 2015; Gaur and Ondrus, 2012; Guo and } \\
\text { Bouwman, 2016b; Hedman and Henningsson, } \\
\text { 2012; Hedman and Henningsson, 2015; } \\
\text { Kanniainen, 2010; Kauffman et al., 2015; } \\
\text { Kazan and Damsgaard, 2013; Liu et al., 2015; } \\
\text { Ok et al, 2013; Ondrus, 2015; Ondrus et al., } \\
\text { 2015; Ondrus and Lyytinen, 2011; Ozcan and } \\
\text { Santos, 2015; Pousttchi, 2008; Pousttchi et al., } \\
\text { 2009; Staykova and Damsgaard, 2015; Van } \\
\text { Bossuyt and Van Hove, 2007; Zhong and } \\
\text { Nieminen, 2015; Zolnowski et al., 2014 }\end{array}$ \\
\hline Desktop analysis & 19 & $\begin{array}{l}\text { Andersson et al., 2013; Gannamaneni et al., } \\
\text { 2015; Ghezzi et al., 2010; Guo and Bouwman, } \\
\text { 2016b; Hedman and Henningsson, 2012; } \\
\text { Hedman and Henningsson, 2015; Juntunen et } \\
\text { al., 2012; Kanniainen, 2010; Kazan and } \\
\text { Damsgaard, 2013; Liu et al., 2015; } \\
\text { Magnire-Watanabe, 2014; Ondrus, 2015; } \\
\text { Ondrus et al., 2015; Ondrus and Lyytinen, } \\
\text { 2011; Ondrus et al., 2009; Ozcan and Santos, } \\
\text { 2015; Staykova and Damsgaard, 2015; Zhong } \\
\text { and Nieminen, 2015 }\end{array}$ \\
\hline Interviews & 19 & $\begin{array}{l}\text { Andersson et al., 2013; Apanasevic, 2013; } \\
\text { Dahlberg, Huurros, et al., 2008; de Reuver et } \\
\text { al., 2015; Gannamaneni et al., 2015; Ghezzi et } \\
\text { al., 2010; Guo and Bouwman, 2016b; Hedman } \\
\text { and Henningsson, 2012; Hedman and } \\
\text { Henningsson, 2015; Juntunen et al., 2012; } \\
\text { Kazan and Damsgaard, 2013; Liu et al., 2015; } \\
\text { Magnire-Watanabe, 2014; Markendahl, 2013; } \\
\text { Ondrus and Lyytinen, 2011; Ondrus et al., } \\
\text { 2009; Ozcan and Santos, 2015; Staykova and } \\
\text { Damsgaard, 2015; Zhong and Nieminen, 2015 }\end{array}$ \\
\hline Focus groups & 3 & $\begin{array}{l}\text { Andersson et al., 2013; Dennehy et al., 2015; } \\
\text { Carton et al., } 2012\end{array}$ \\
\hline Survey & 2 & Carton et al., 2012; Pousttchi, 2008 \\
\hline
\end{tabular}




\begin{tabular}{|c|c|c|}
\hline Methods & No. of papers & References \\
\hline Case study & 21 & $\begin{array}{l}\text { Andersson et al., 2013; Apanasevic, 2013; } \\
\text { Carton et al., 2012; Dahlberg, Huurros, et al., } \\
\text { 2008; de Reuver et al., 2015; Gannamaneni et } \\
\text { al., 2015; Ghezzi et al., 2010; Guo and } \\
\text { Bouwman, 2016b; Hedman and Henningsson, } \\
\text { 2012; Hedman and Henningsson, 2015; } \\
\text { Juntunen et al., 2012; Kazan and Damsgaard, } \\
\text { 2013; Magnire-Watanabe, 2014; Markendahl, } \\
\text { 2013; Ondrus et al., 2015; Ondrus and } \\
\text { Lyytinen, 2011; Ondrus et al., 2009; Ozcan and } \\
\text { Santos, 2015; Staykova and Damsgaard, 2015; } \\
\text { Zolnowski et al., 2014; Zhong and Nieminen, } \\
\text { 2015 }\end{array}$ \\
\hline $\begin{array}{l}\text { Development of systems and } \\
\text { algorithms }\end{array}$ & 0 & \\
\hline Mathematical modeling & 1 & Kauffman et al., 2015 \\
\hline Experiment/ simulation & 1 & Kauffman et al., 2015 (simulation) \\
\hline Prototype & 0 & \\
\hline Usability test & 0 & \\
\hline Empirical test & 0 & \\
\hline Proof of concept & 1 & Dennehy et al., 2015 \\
\hline
\end{tabular}

Table B.4. Research methods used in studies on mobile payments' law and regulation aspects.

\begin{tabular}{|c|c|c|}
\hline Methods & No. of papers & References \\
\hline Total No. of papers & 4 & \\
\hline $\begin{array}{l}\text { Conceptual work } \\
\text { (Theoretical discussion, } \\
\text { speculation, } \\
\text { theory-building) }\end{array}$ & 3 & Kemp, 2013; Vandezande, 2014; Liu, 2015 \\
\hline Desktop analysis & 1 & Lim, 2008 \\
\hline Interviews & 1 & Lim, 2008 \\
\hline Focus groups & 0 & \\
\hline Survey & 0 & \\
\hline Case study & 2 & Lim, 2008; Liu, 2015 \\
\hline $\begin{array}{l}\text { Development of systems and } \\
\text { algorithms }\end{array}$ & 0 & \\
\hline Mathematical modeling & 0 & \\
\hline Experiment/ simulation & 0 & \\
\hline Prototype & 0 & \\
\hline Usability test & 0 & \\
\hline Empirical test & 0 & \\
\hline Proof of concept & 0 & \\
\hline
\end{tabular}

ISSN 2183-0606 
Table B.5. Research methods used in studies on mobile payments' merchant adoption.

\begin{tabular}{|c|c|c|}
\hline Methods & No. of papers & References \\
\hline Total No. of papers & 4 & \\
\hline $\begin{array}{l}\text { Conceptual work } \\
\text { (Theoretical discussion, } \\
\text { speculation, } \\
\text { theory-building) }\end{array}$ & 3 & $\begin{array}{l}\text { Apanasevic et al., 2016; Guo and Bouwman, } \\
\text { 2016a; Mallat and Tuunainen, } 2008\end{array}$ \\
\hline Desktop analysis & 3 & $\begin{array}{l}\text { Apanasevic et al., 2016; Guo and Bouwman, } \\
\text { 2016a; Mallat and Tuunainen, } 2008\end{array}$ \\
\hline Interviews & 3 & $\begin{array}{l}\text { Apanasevic et al., 2016; Guo and Bouwman, } \\
\text { 2016a; Mallat and Tuunainen, } 2008\end{array}$ \\
\hline Focus groups & 0 & \\
\hline Survey & 0 & \\
\hline Case study & 1 & Apanasevic et al., 2016 \\
\hline $\begin{array}{l}\text { Development of systems and } \\
\text { algorithms }\end{array}$ & 0 & \\
\hline Mathematical modeling & 1 & Wiechert et al., 2009 \\
\hline Experiment/ simulation & 0 & \\
\hline Prototype & 0 & \\
\hline Usability test & 0 & \\
\hline Empirical test & 0 & \\
\hline Proof of concept & 0 & \\
\hline
\end{tabular}

Table B.6. Research methods used in studies on mobile payment services.

\begin{tabular}{lcl}
\hline Methods & No. of papers & References \\
\hline Total No. of papers & 4 & \\
\hline $\begin{array}{l}\text { Conceptual work } \\
\text { (Theoretical discussion, }\end{array}$ & 2 & Dahlberg, 2015; Hu et al., 2008 \\
$\begin{array}{l}\text { speculation, } \\
\text { theory-building) }\end{array}$ & & \\
\hline Desktop analysis & 1 & Zhong, 2009 \\
\hline Interviews & 1 & Olsen et al., 2012 \\
\hline Focus groups & 0 & \\
\hline Survey & 0 & \\
\hline Case study & 1 & Zhong, 2009 \\
\hline $\begin{array}{l}\text { Development of systems and } \\
\text { lgorithms }\end{array}$ & 0 & \\
\hline Mathematical modeling & 0 & \\
\hline Experiment/ simulation & 0 & \\
\hline Prototype & 1 & Olsen et al., 2012 \\
\hline Usability test & 1 & Olsen et al., 2012 \\
\hline Empirical test & 0 & \\
\hline
\end{tabular}




\begin{tabular}{lcc}
\hline Methods & No. of papers & References \\
\hline Proof of concept & 0 & \\
\hline
\end{tabular}

\section{Appendix C. Papers on mobile payment adoption}

Table C.1. Classification of papers on customer adoption of mobile payments by topics.

\begin{tabular}{|c|c|c|}
\hline Addressed question & Frequency & References \\
\hline $\begin{array}{l}\text { Understanding and } \\
\text { explaining how different } \\
\text { factors influence the } \\
\text { intention to use or to adopt } \\
\text { mobile payments }\end{array}$ & 42 & $\begin{array}{l}\text { Arvidsson, 2014; Augsburg and Hedman, 2014; } \\
\text { Chen, 2008; Chen and Huang, 2013; Cocosila } \\
\text { and Trabelsi, 2016; Dahlberg and Ö̈rni, 2007; } \\
\text { de Kerviler et al., 2016; Di Pietro et al., 2015; } \\
\text { Gerpott and Kornmeier, 2009; Goeke and } \\
\text { Pousttchi, 2010; Kim et al., 2010; Leong et al., } \\
\text { 2013; Li et al., 2014; Liébana-Cabanillas et al., } \\
\text { 2015; Liébana-Cabanillas et al., 2014a; } \\
\text { Liébana-Cabanillas et al., 2014b; } \\
\text { Liébana-Cabanillas et al., 2014c; Liu et al., } \\
\text { 2011; Liu et al., 2013; Lu et al., 2011; Mallat et } \\
\text { al., 2009; Morosan and DeFranco, 2016; Moroni } \\
\text { et al., 2015; Oliveira et al., 2016; Pham and Ho, } \\
\text { 2015; Ramos-de-Luna et al., 2016; Schierz et } \\
\text { al., 2010; Shaw, 2014; Shin, 2009; Silic et al., } \\
\text { 2014; Slade et al., 2015a; Slade et al., 2015b; } \\
\text { Tan et al., 2014; Teo et al., 2015; Theodora et } \\
\text { al., 2010; Viehland and Leong, 2007; Xin et al., } \\
\text { 2013; Yang et al., 2012; Zhang et al., 2011; } \\
\text { Zhao and Kurnia, 2014; Zhou, 2011; Zhou, } \\
\text { 2014b }\end{array}$ \\
\hline $\begin{array}{l}\text { Investigation if model } \\
\text { constructs influence actual } \\
\text { use of mobile payments }\end{array}$ & 3 & $\begin{array}{l}\text { Amoroso and Magnier-Watanabe, } 2012 \text {; } \\
\text { Koening-Lewis et al., 2015; Mallat, } 2007\end{array}$ \\
\hline $\begin{array}{l}\text { Post-adoption - continuance } \\
\text { use and retention of } \\
\text { consumers }\end{array}$ & 2 & Zhou, 2013; Zhou, 2014a \\
\hline $\begin{array}{l}\text { Willingness to use smart } \\
\text { phones for mobile payments }\end{array}$ & 2 & Duane et al., 2014; O’Reilly et al., 2012 \\
\hline $\begin{array}{l}\text { Examination of the sources } \\
\text { of perceived risks }\end{array}$ & 2 & Yang et al., 2015; Cocosila and Trabelsi, 2016 \\
\hline $\begin{array}{l}\text { Evaluation/forecasting of } \\
\text { demand for mobile payment }\end{array}$ & 1 & Brakewood et al., 2014 \\
\hline $\begin{array}{l}\text { Analysis of customer } \\
\text { requirements }\end{array}$ & 1 & Petrova, 2008 \\
\hline $\begin{array}{l}\text { Explanation of people's } \\
\text { behaviour towards the } \\
\text { mobile payments }\end{array}$ & 1 & Molina-Castillo et al., 2016 \\
\hline
\end{tabular}




\begin{tabular}{lcl}
\hline Addressed question & Frequency & References \\
\hline $\begin{array}{l}\text { Examination of the sources } \\
\text { of perceived value }\end{array}$ & 1 & Cocosila and Trabelsi, 2016 \\
\hline
\end{tabular}

Table C.2. Theoretical perspectives used in research on customer adoption of mobile payments.

\begin{tabular}{|c|c|c|c|}
\hline Discipline & $\begin{array}{l}\text { Theories, models, } \\
\text { constructs }\end{array}$ & References & Frequency \\
\hline \multirow[t]{7}{*}{$\begin{array}{l}\text { Psycholo-gical/so- } \\
\text { ciological }\end{array}$} & $\begin{array}{l}\text { TAM (and other } \\
\text { theories) }\end{array}$ & $\begin{array}{l}\text { Chen and Huang, 2013; Duane et al., } \\
\text { 2014; Gerpott and Kornmeier, 2009; } \\
\text { Goeke and Pousttchi, 2010; Kim et } \\
\text { al., 2010; Leong et al., 2013; Li et } \\
\text { al., 2014; Liébana-Cabanillas et al., } \\
\text { 2015 (TRA and TPB); Liu et al., } \\
\text { 2011; Molina-Castillo et al., 2016 } \\
\text { (other); Ramos-de-Luna et al., 2016 } \\
\text { (TRA and TPB); Petrova, 2008; } \\
\text { Schierz et al., 2010; Shaw, 2014; Tan } \\
\text { et al., 2014; Zhou, 2013; Theodora et } \\
\text { al., 2010; Viehland and Leong, 2007; } \\
\text { Zhang et al., 2011 }\end{array}$ & 19 \\
\hline & $\begin{array}{l}\text { DoI (and other } \\
\text { theories) }\end{array}$ & $\begin{array}{l}\text { Dahlberg and Öörni, } 2007 \text { (TPB); } \\
\text { Mallat, 2007; Pham and Ho, } 2015\end{array}$ & 3 \\
\hline & $\begin{array}{l}\text { TAM and DoI } \\
\text { (and other } \\
\text { theories) }\end{array}$ & $\begin{array}{l}\text { Arvidsson, 2014; Augsburg and } \\
\text { Hedman, 2014; Chen, 2008; Di } \\
\text { Pietro et al., 2015 (UTAUT); Lu et } \\
\text { al., 2011; Mallat et al., 2009; Moroni } \\
\text { et al., 2015; Yang et al., 2012; Zhou, } \\
2011\end{array}$ & 9 \\
\hline & $\begin{array}{l}\text { UTAUT (and } \\
\text { other theories) }\end{array}$ & $\begin{array}{l}\text { Shin, 2009; Slade et al., 2015a } \\
\text { (other); Teo et al., } 2015\end{array}$ & 3 \\
\hline & $\begin{array}{l}\text { TAM and } \\
\text { UTAUT (and } \\
\text { other theories) }\end{array}$ & $\begin{array}{l}\text { Amoroso and Magnier-Watanabe, } \\
\text { 2012; Koening-Lewis et al., 2015; } \\
\text { Liébana-Cabanillas et al., 2014a } \\
\text { (TRA); Liébana-Cabanillas et al., } \\
\text { 2014b (TRA); Liébana-Cabanillas et } \\
\text { al., 2014c (TRA) }\end{array}$ & 5 \\
\hline & $\begin{array}{l}\text { UTAUT2 (and } \\
\text { other theories) }\end{array}$ & $\begin{array}{l}\text { Morosan and DeFranco, 2016; } \\
\text { Oliveira et al., } 2016 \text { (DoI and other); } \\
\text { Slade et al., 2015b }\end{array}$ & 3 \\
\hline & Other theories & $\begin{array}{l}\text { Cocosila and Trabelsi, 2016; de } \\
\text { Kerviler et al., 2016; Liu et al., 2013; } \\
\text { O'Reilly et al., 2012; Xin et al., 2013; } \\
\text { Yang et al., 2015; Zhao and Kurnia, } \\
\text { 2014; Zhou, 2014a; Zhou, 2014b }\end{array}$ & 9 \\
\hline \multirow[t]{2}{*}{$\begin{array}{l}\text { Marketing/ } \\
\text { services }\end{array}$} & No theory used & $\begin{array}{l}\text { Brakewood et al., 2014; Silic et al., } \\
2014\end{array}$ & 2 \\
\hline & & Total & 53 \\
\hline
\end{tabular}


Table C.3. Constructs used in adoption studies related to service characteristics.

\begin{tabular}{|c|c|c|}
\hline Construct & Frequency* & References \\
\hline $\begin{array}{l}\text { Perceived ease of } \\
\text { use }\end{array}$ & 31 & $\begin{array}{l}\text { Amoroso and Magnier-Watanabe, 2012; Arvidsson, 2014; } \\
\text { Augsburg and Hedman, 2014; Chen, 2008; Chen and } \\
\text { Huang, 2013; Dahlberg and Öörni, 2007; Di Pietro et al., } \\
\text { 2015; Duane et al., 2014; Goeke and Pousttchi, 2010; } \\
\text { Kim et al., 2010; Koening-Lewis et al., 2015; Leong et } \\
\text { al., 2013; Li et al., 2014; Liébana-Cabanillas et al., 2015; } \\
\text { Liébana-Cabanillas et al., 2014a; Liébana-Cabanillas et } \\
\text { al., 2014b; Liébana-Cabanillas et al., 2014c; Liu et al., } \\
\text { 2011; Mallat et al., 2009; Molina-Castillo et al., 2016; } \\
\text { Moroni et al., 2015; Pham and Ho, 2015; Ramos-de-Luna } \\
\text { et al., 2016; Schierz et al., 2010; Shaw, 2014; Shin, 2009; } \\
\text { Tan et al., 2014; Theodora et al., 2010; Viehland and } \\
\text { Leong, 2007; Zhang et al., 2011; Zhou, 2011 }\end{array}$ \\
\hline $\begin{array}{l}\text { Perceived } \\
\text { usefulness }\end{array}$ & 29 & $\begin{array}{l}\text { Amoroso and Magnier-Watanabe, 2012; Augsburg and } \\
\text { Hedman, 2014; Chen, 2008; Chen and Huang, 2013; Di } \\
\text { Pietro et al., 2015; Duane et al., 2014; Goeke and } \\
\text { Pousttchi, 2010; Kim et al., 2010; Koening-Lewis et al., } \\
\text { 2015; Leong et al., 2013; Li et al., 2014; } \\
\text { Liébana-Cabanillas et al., 2015; Liébana-Cabanillas et } \\
\text { al., 2014a; Liébana-Cabanillas et al., 2014b; } \\
\text { Liébana-Cabanillas et al., 2014c; Mallat et al., 2009; } \\
\text { Molina-Castillo et al., 2016; Moroni et al., 2015; Pham } \\
\text { and Ho, 2015; Ramos-de-Luna et al., 2016; Schierz et al., } \\
\text { 2010; Shaw, 2014; Shin, 2009; Tan et al., 2014; Theodora } \\
\text { et al., 2010; Viehland and Leong, 2007; Zhang et al., } \\
\text { 2011; Zhao and Kurnia, 2014; Zhou, 2011 }\end{array}$ \\
\hline
\end{tabular}

Perceived risk (security, privacy, financial)
20 Zhou, 2011

Amoroso and Magnier-Watanabe, 2012; Chen, 2008; Chen and Huang, 2013; Cocosila and Trabelsi, 2016; de Kerviler et al., 2016; Gerpott and Kornmeier, 2009; Koening-Lewis et al., 2015; Li et al., 2014; Liébana-Cabanillas et al., 2015; Liébana-Cabanillas et al., 2014a; Liébana-Cabanillas et al., 2014b; Liébana-Cabanillas et al., 2014c; Liu et al., 2013; Morosan and DeFranco, 2016; Slade et al., 2015a; Slade et al., 2015b; Tan et al., 2014; Yang et al., 2015; Zhang et al., 2011; Zhao and Kurnia, 2014

Perceived security $16 \quad$ Arvidsson, 2014; Dahlberg and Öörni, 2007; Di Pietro et al., 2015; Goeke and Pousttchi, 2010; Lu et al., 2011; Mallat, 2007; Moroni et al., 2015; Petrova, 2008; Pham and Ho, 2015; Ramos-de-Luna et al., 2016; Schierz et al., 2010; Shin, 2009; Silic et al., 2014; Viehland and Leong, 2007; Yang et al., 2012; Zhou, 2011

(Perceived) 16 compatibility

16

Arvidsson, 2014; Augsburg and Hedman, 2014; Chen, 2008; Dahlberg and Öörni, 2007; Di Pietro et al., 2015; Kim et al., 2010; Li et al., 2014; Lu et al., 2011; Mallat, 2007; Mallat et al., 2009; Moroni et al., 2015; Pham and Ho, 2015; Ramos-de-Luna et al., 2016; Schierz et al., 2010; Yang et al., 2012; Zhao and Kurnia, 2014 


\begin{tabular}{|c|c|c|}
\hline Construct & Frequency $^{*}$ & References \\
\hline Cost (perceived) & 13 & $\begin{array}{l}\text { Arvidsson, 2014; Cocosila and Trabelsi, 2016; Goeke and } \\
\text { Pousttchi, 2010; Leong et al., 2013; Lu et al., 2011; } \\
\text { Mallat, 2007; Moroni et al., 2015; Petrova, 2008; Pham } \\
\text { and Ho, 2015; Tan et al., 2014; Yang et al., 2012; Zhao } \\
\text { and Kurnia, 2014; Zhou, 2011 }\end{array}$ \\
\hline $\begin{array}{l}\text { Performance } \\
\text { expectancy }\end{array}$ & 8 & $\begin{array}{l}\text { Gerpott and Kornmeier, 2009; Morosan and DeFranco, } \\
\text { 2016; Oliveira et al., 2016; Teo et al., 2015; Slade et al., } \\
\text { 2015a; Slade et al., 2015b; Zhou, 2014a; Zhou, 2014b }\end{array}$ \\
\hline Convenience & 7 & $\begin{array}{l}\text { Augsburg and Hedman, 2014; Chen, 2008; Dahlberg and } \\
\text { Öörni, 2007; Kim et al., 2010; Petrova, 2008; Teo et al., } \\
\text { 2015; Viehland and Leong, 2007 }\end{array}$ \\
\hline Relative advantage & 6 & $\begin{array}{l}\text { Arvidsson, 2014; Augsburg and Hedman, 2014; Dahlberg } \\
\text { and Öörni, 2007; Lu et al., 2011; Mallat, 2007; Yang et } \\
\text { al., } 2012\end{array}$ \\
\hline Effort expectancy & 6 & $\begin{array}{l}\text { Morosan and DeFranco, 2016; Oliveira et al., 2016; Slade } \\
\text { et al., 2015a; Slade et al., 2015b; Teo et al., 2015; Zhou, } \\
\text { 2014b }\end{array}$ \\
\hline $\begin{array}{l}\text { Added value } \\
\text { services/ } \\
\text { additional value }\end{array}$ & 3 & $\begin{array}{l}\text { Augsburg and Hedman, 2014; Petrova, 2008; Pham and } \\
\text { Ho, } 2015\end{array}$ \\
\hline
\end{tabular}

* Constructs were included if they were mentioned at least three times.

Table C.4. Constructs related to customer's characteristics.

\begin{tabular}{|c|c|c|}
\hline Criteria & Frequency* & References \\
\hline $\begin{array}{l}\text { Trust in actors or } \\
\text { services }\end{array}$ & 25 & $\begin{array}{l}\text { Amoroso and Magnier-Watanabe, 2012; Arvidsson, 2014; } \\
\text { Dahlberg and Öörni, 2007; Duane et al., 2014; Goeke } \\
\text { and Pousttchi, 2010; Leong et al., 2013; Li et al., 2014; } \\
\text { Liébana-Cabanillas et al., 2015; Liébana-Cabanillas et } \\
\text { al., 2014a; Liébana-Cabanillas et al., 2014b; } \\
\text { Liébana-Cabanillas et al., 2014c; Lu et al., 2011; Mallat, } \\
\text { 2007; O'Reilly et al., 2012; Petrova, 2008; Pham and Ho, } \\
\text { 2015; Shaw, 2014; Shin, 2009; Slade et al., 2015a; Slade } \\
\text { et al., 2015b; Xin et al., 2013; Zhao and Kurnia, 2014; } \\
\text { Zhou, 2011; Zhou, 2013; Zhou, 2014a; Zhou, 2014b }\end{array}$ \\
\hline $\begin{array}{l}\text { Demographic data } \\
\text { (age }^{\mathrm{a}}, \text { gender }^{\mathrm{b}} \\
\text { income }^{\mathrm{c}} \\
\text { education }^{\mathrm{d}} \\
\left.\text { ethnicity }^{\mathrm{e}}\right)\end{array}$ & 15 & 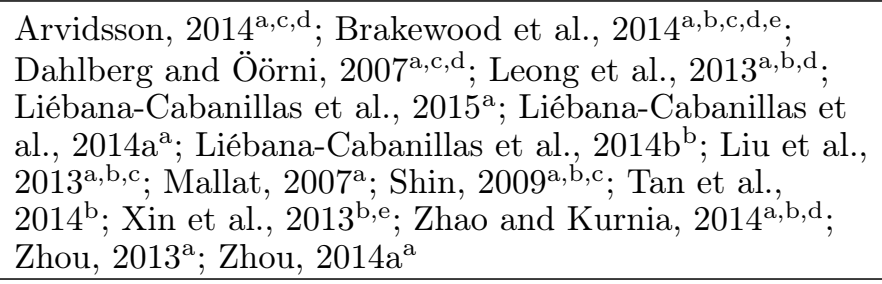 \\
\hline $\begin{array}{l}\text { Personal } \\
\text { innovativeness in } \\
\text { information } \\
\text { technology }\end{array}$ & 11 & $\begin{array}{l}\text { Chen and Huang, 2013; Duane et al., 2014; Gerpott and } \\
\text { Kornmeier, 2009; Kim et al., 2010; Leong et al., 2013; } \\
\text { Oliveira et al., 2016; Pham and Ho, 2015; } \\
\text { Ramos-de-Luna et al., 2016; Slade et al., 2015a; Tan et } \\
\text { al., 2014; Yang et al., } 2012\end{array}$ \\
\hline
\end{tabular}




\begin{tabular}{|c|c|c|}
\hline Criteria & Frequency* & References \\
\hline $\begin{array}{l}\text { Knowledge or } \\
\text { previous } \\
\text { experience of } \\
\text { technology or } \\
\text { service }\end{array}$ & 10 & $\begin{array}{l}\text { Dahlberg and Öörni, 2007; Gerpott and Kornmeier, } \\
\text { 2009; Kim et al., 2010; Koening-Lewis et al., 2015; Leong } \\
\text { et al., 2013; Li et al., 2014; Liébana-Cabanillas et al., } \\
\text { 2014c; Theodora et al., 2010; Xin et al., 2013; Zhao and } \\
\text { Kurnia, } 2014\end{array}$ \\
\hline $\begin{array}{l}\text { Attitude towards } \\
\text { use }\end{array}$ & 9 & $\begin{array}{l}\text { Amoroso and Magnier-Watanabe, 2012; Di Pietro et al., } \\
\text { 2015; Gerpott and Kornmeier, 2009; Liébana-Cabanillas } \\
\text { et al., 2014a; Liébana-Cabanillas et al., 2014b; } \\
\text { Liébana-Cabanillas et al., 2014c; Ramos-de-Luna et al., } \\
\text { 2016; Schierz et al., 2010; Shin, } 2009\end{array}$ \\
\hline $\begin{array}{l}\text { Mobility/ } \\
\text { individual mobility }\end{array}$ & 5 & $\begin{array}{l}\text { Kim et al., 2010; Mallat et al., 2009; Petrova, } 2008 ; \\
\text { Ramos-de-Luna et al., 2016; Schierz et al., } 2010\end{array}$ \\
\hline Self-efficacy & 5 & $\begin{array}{l}\text { Duane et al., 2014; Molina-Castillo et al., 2016; Shaw, } \\
\text { 2014; Shin, 2009; Tan et al., } 2014\end{array}$ \\
\hline $\begin{array}{l}\text { Hedonistic } \\
\text { motivation (fun, } \\
\text { enjoyment, } \\
\text { entertainment) }\end{array}$ & 5 & $\begin{array}{l}\text { de Kerviler et al., 2016; Koening-Lewis et al., 2015; } \\
\text { Morosan and DeFranco, 2016; Oliveira et al., 2016; Slade } \\
\text { et al., 2015b }\end{array}$ \\
\hline $\begin{array}{l}\text { Behavioural } \\
\text { intention (to } \\
\text { use/adopt) }\end{array}$ & 3 & $\begin{array}{l}\text { Amoroso and Magnier-Watanabe, 2012; Oliveira et al., } \\
\text { 2016; Koening-Lewis et al., } 2015\end{array}$ \\
\hline
\end{tabular}

* Constructs were included if they were mentioned at least three times.

Table C.5. Constructs related to external factors.

\begin{tabular}{lcl}
\hline Criteria & Frequency* $^{*}$ & References \\
\hline Social influence & 15 & Amoroso and Magnier-Watanabe, 2012; Gerpott and \\
& & Kornmeier, 2009; Koening-Lewis et al., 2015; Leong et \\
& al., 2013; Liébana-Cabanillas et al., 2014a; \\
& Liébana-Cabanillas et al., 2014b; Liébana-Cabanillas et \\
& al., 2014c; Morosan and DeFranco, 2016; Oliveira et al., \\
& 2016; Shin, 2009; Slade et al., 2015a; Slade et al., 2015b; \\
& Teo et al., 2015; Yang et al., 2012; Zhao and Kurnia, 2014 \\
\hline Subjective norm & Dahlberg and Öörni, 2007; Liébana-Cabanillas et al., \\
& 2014a; Liébana-Cabanillas et al., 2014b; \\
& Liébana-Cabanillas et al., 2014c; Ramos-de-Luna et al., \\
& $2016 ;$ Schierz et al., 2010; Yang et al., 2012; Zhang et al., \\
& 2011 \\
\hline Facilitating & & Amoroso and Magnier-Watanabe, 2012; Koening-Lewis \\
conditions & et al., 2015; Morosan and DeFranco, 2016; Oliveira et al., \\
& $2016 ;$ Slade et al., 2015b; Teo et al., 2015 \\
\hline External influence & Liébana-Cabanillas et al., 2014a; Liébana-Cabanillas et \\
& & al., 2014b; Liébana-Cabanillas et al., 2014c; \\
\hline Use situation/ & Mallat, 2007; Mallat et al., 2009; Viehland and Leong, \\
context & 2007 \\
\hline
\end{tabular}

* Constructs were included if they were mentioned at least three times. 


\section{Appendix D. Papers on mobile payment technology}

Table D.1. Classification of papers on technology by topics.

\begin{tabular}{lll}
\hline Addressed question & Frequency & References \\
\hline Papers addressing security & 40 & Ahamad et al., 2014; Almuairfi et al., 2014; \\
issues: security architecture, & Ammayappan, 2015; Bottoni and Deni, 2007; \\
security mechanisms, & Clarke, 2008; Conti et al., 2009; Fan and \\
security protocols, & Huang, 2010; Ferreira et al., 2009; Fun et al., \\
authentication and & 2008; Godbole and Pais, 2008; Gold et al., \\
cryptography, anonymity, & 2015; Hassinen et al., 2008; Hwang et al., 2007; \\
privacy, non-repudiation & Isaac and Zeadally, 2014; Isaac et al., 2012; \\
& Kadambi et al., 2009; Konidala et al., 2012; \\
& Kumar and Rabara, 2010; Lee et al., 2007; Lei \\
& et al., 2009; Li et al., 2012; Lin et al., 2008; Luo \\
& et al., 2016; Martínez-Peláez et al., 2015; \\
& Munch-Ellingsen et al., 2015; Jiang et al., 2009; \\
& Ou and Ou, 2009; Pasquet et al., 2008; Pasquet \\
& and Gerbaix, 2016; Popescu, 2009; Sung et al., \\
& 2015; Veeraraghavan, et al., 2016; Wang et al., \\
& 2008; Yang, 2014; Yang and Chang, 2012; Yang \\
& and Lin, 2016; Yang et al., 2010; Zhang et al., \\
& 2008; Zhu and Rice, 2009; Zhu et al., 2012
\end{tabular}

Proposals of new mobile payment architectures, systems, and schemes

25

Ahamad et al., 2014; Basili et al., 2014; Ferreira et al., 2009; Ghiron et al., 2009; Grønli et al., 2015; Hwang et al., 2007; Kadambi et al., 2009; Konidala et al., 2012; Kousaridas et al., 2008; Kumar and Rabara, 2010; Lee et al., 2007; Lin et al., 2008; Luo et al., 2016; Martínez-Peláez et al., 2015; Popescu, 2009; Rahimian and Habibi, 2008; Rodrigues et al., 2014; Sung et al., 2015; Veeraraghavan, et al., 2016; Yang and Chang, 2012; Yang and Lin, 2016; Yang et al., 2010; Zhang et al., 2008; Zhu and Rice, 2009; Zhu et al., 2012

Proposals of new mobile payment protocols
17

Ahamad et al., 2014; Ammayappan, 2015;

Bottoni and Deni, 2007; Fan and Huang, 2010; Fun et al., 2008; Godbole and Pais, 2008; Isaac and Zeadally, 2014; Isaac et al., 2012; Kumar and Rabara, 2010; Lei et al., 2009; Li et al., 2012; Jiang et al., 2009; Rodrigues et al., 2014; Wang et al., 2008; Yang, 2014; Zhang et al., 2008; Zhu and Rice, 2009

Proposals of more efficient, optimized, and

11 lightweighted solutions

Technology description

5
Godbole and Pais, 2008; Grønli et al., 2015; Isaac and Zeadally, 2014; Isaac et al., 2012; Lee et al., 2007; Lei et al., 2009; Ou and Ou, 2009; Popescu, 2009; Yang, 2014; Zhu and Rice, 2009; Zhu et al., 2012

Basili et al., 2014; Massoth and Bingel, 2009; Ondrus and Pigneur, 2009; Pasquet et al., 2008; Yang et al., 2010 


\begin{tabular}{lcl}
\hline Addressed question & Frequency & References \\
\hline $\begin{array}{l}\text { Proposals of solutions with } \\
\text { lower computational costs }\end{array}$ & 4 & $\begin{array}{l}\text { Fan and Huang, 2010; Li et al, 2012; Lin et al., } \\
\text { 2008; Yang and Chang, 2012 }\end{array}$ \\
\hline $\begin{array}{l}\text { Comparison of different } \\
\text { payment systems } \\
\text { (debit/credit card, }\end{array}$ & 3 & $\begin{array}{l}\text { Bottoni and Deni, 2007; Konidala et al., 2012; } \\
\text { Massoth and Bingel, 2009 }\end{array}$ \\
$\begin{array}{l}\text { contactless credit/debit } \\
\text { card/, electronic cash, and } \\
\text { mobile NFC payment) }\end{array}$ & & \\
\hline $\begin{array}{l}\text { Development of mobile } \\
\text { payment solutions for } \\
\text { restricted connectivity } \\
\text { scenarios }\end{array}$ & 2 & Isaac et al., 2012; Li et al, 2012 \\
\hline
\end{tabular}

\section{Appendix E. Papers on business aspects of mobile payments}

Table E.1. Classification of papers on business aspects by topics.

\begin{tabular}{|c|c|c|}
\hline $\begin{array}{l}\text { Addressed } \\
\text { question }\end{array}$ & Frequency & References \\
\hline $\begin{array}{l}\text { Business } \\
\text { ecosystem of } \\
\text { mobile payments } \\
\text { (actors/stakehold- } \\
\text { ers, strategies, } \\
\text { roles and issues) }\end{array}$ & 23 & $\begin{array}{l}\text { Andersson et al., 2013; Au and Kauffman, 2008; Carton } \\
\text { et al., 2012; Dennehy et al., 2015; Gannamaneni et al., } \\
\text { 2015; Ghezzi et al., 2010; Guo and Bouwman, 2016b; } \\
\text { Hedman and Henningsson, 2012; Hedman and } \\
\text { Henningsson, 2015; Kanniainen, 2010; Kazan and } \\
\text { Damsgaard, 2013; Liu et al., 2015; Magnier-Watanabe, } \\
\text { 2014; Markendahl, 2013; Ok et al, 2013; Ondrus, 2015; } \\
\text { Ondrus et al., 2015; Ondrus et al., 2009; Ozcan and } \\
\text { Santos, 2015; Pousttchi, 2008; Staykova and Damsgaard, } \\
\text { 2015; Van Bossuyt and Van Hove, 2007; Zhong and } \\
\text { Nieminen, 2015 }\end{array}$ \\
\hline $\begin{array}{l}\text { Business models } \\
\text { (aspects, issues) }\end{array}$ & 11 & $\begin{array}{l}\text { Au and Kauffman, 2008; Carton et al., 2012; Dennehy et } \\
\text { al., 2015; Gannamaneni et al., 2015; Juntunen et al., } \\
\text { 2012; Ondrus, 2015; Ondrus and Lyytinen, 2011; Ondrus } \\
\text { et al., 2009; Pousttchi, 2008; Pousttchi et al., 2009; } \\
\text { Zolnowski et al., 2014 }\end{array}$ \\
\hline $\begin{array}{l}\text { Collaboration } \\
\text { issues (inter-firm } \\
\text { relationship) }\end{array}$ & 10 & $\begin{array}{l}\text { Andersson et al., 2013; Apanasevic, 2013; de Reuver et } \\
\text { al., 2015; Gannamaneni et al., 2015; Hedman and } \\
\text { Henningsson, 2012; Hedman and Henningsson, 2015; } \\
\text { Magnire-Watanabe, 2014; Ondrus, 2015; Ondrus et al., } \\
\text { 2015; Ozcan and Santos, } 2015\end{array}$ \\
\hline $\begin{array}{l}\text { Market-level } \\
\text { analysis }\end{array}$ & 10 & $\begin{array}{l}\text { Apanasevic, 2013; Au and Kauffman, 2008; Dahlberg, } \\
\text { Huurros, et al., 2008; Ghezzi et al., 2010; Liu et al., 2015; } \\
\text { Magnire-Watanabe, 2014; Markendahl, 2013; Ondrus et } \\
\text { al., 2009; Ozcan and Santos, 2015; Staykova and } \\
\text { Damsgaard, 2015 }\end{array}$ \\
\hline Market challenges & 4 & $\begin{array}{l}\text { Au and Kauffman, 2008; Apanasevic, 2013; Liu et al., } \\
\text { 2015; Staykova and Damsgaard, } 2015\end{array}$ \\
\hline
\end{tabular}




\begin{tabular}{lcl}
\hline $\begin{array}{l}\text { Addressed } \\
\text { question }\end{array}$ & Frequency & References \\
\hline Firm-level analysis & 3 & $\begin{array}{l}\text { Au and Kauffman, 2008; Gaur and Ondrus, 2012; } \\
\text { Kauffman et al., 2015 }\end{array}$ \\
\hline $\begin{array}{l}\text { Mobile payment } \\
\text { use cases }\end{array}$ & 2 & Ok et al, 2013; Pousttchi, 2008 \\
\hline
\end{tabular}

Table E.2. Theoretical perspectives used in research on business aspects of mobile payments.

\begin{tabular}{|c|c|c|c|}
\hline Discipline & $\begin{array}{l}\text { Theories, mod- } \\
\text { els, concepts }\end{array}$ & References & Frequency \\
\hline \multirow[t]{4}{*}{ Economics } & $\begin{array}{l}\text { Network } \\
\text { economies }\end{array}$ & $\begin{array}{l}\text { Au and Kauffman, 2008; Apanasevic, 2013; } \\
\text { Ondrus et al., } 2009\end{array}$ & 3 \\
\hline & $\begin{array}{l}\text { Industry evolu- } \\
\text { tion, dominant } \\
\text { design }\end{array}$ & $\begin{array}{l}\text { Dahlberg, Huurros, et al., 2008; Ondrus et } \\
\text { al., 2009; Ozcan and Santos, } 2015\end{array}$ & 3 \\
\hline & Switching costs & $\mathrm{Au}$ and Kauffman, 2008; Apanasevic, 2013 & 2 \\
\hline & Other theories & $\begin{array}{l}\text { Magnire-Watanabe, 2014; Ozcan and San- } \\
\text { tos, } 2015\end{array}$ & 2 \\
\hline \multirow[t]{5}{*}{$\begin{array}{l}\text { Organisa-tional } \\
\text { relations }\end{array}$} & $\begin{array}{l}\text { Business ecosys- } \\
\text { tems }\end{array}$ & $\begin{array}{l}\text { Guo and Bouwman, 2016b; Hedman and } \\
\text { Henningsson, 2012; Hedman and Hennings- } \\
\text { son, 2015; Liu et al., 2015; Zhong and Niem- } \\
\text { inen, 2015 }\end{array}$ & 5 \\
\hline & $\begin{array}{l}\text { Network per- } \\
\text { spective }\end{array}$ & Andersson et al., 2013; Markendahl, 2013 & 2 \\
\hline & Coopetition & Andersson et al., 2013; Apanasevic, 2013 & 2 \\
\hline & Other theories & $\begin{array}{l}\text { Dennehy et al., 2015; de Reuver et al., 2015; } \\
\text { Hedman and Henningsson, 2015; Liu et al., } \\
\text { 2015; Ozcan and Santos, } 2015\end{array}$ & 5 \\
\hline & No theory & $\begin{array}{l}\text { Ghezzi et al., 2010; Kanniainen, 2010; Ok } \\
\text { et al, 2013; Pousttchi, } 2008\end{array}$ & 4 \\
\hline \multirow[t]{2}{*}{$\begin{array}{l}\text { Strategic } \\
\text { agement }\end{array}$} & Business Model & $\begin{array}{l}\text { Apanasevic, 2013; Juntunen et al., 2012; } \\
\text { Ondrus and Lyytinen, 2011; Ondrus et al., } \\
\text { 2009; Pousttchi et al., 2009; Zolnowski et } \\
\text { al., } 2014\end{array}$ & 6 \\
\hline & $\begin{array}{l}\text { Platforms, two- } \\
\text { sided market }\end{array}$ & $\begin{array}{l}\text { de Reuver et al., 2015; Gannamaneni et } \\
\text { al., 2015; Kazan and Damsgaard, 2013; On- } \\
\text { drus, 2015; Ondrus et al., 2009; Ondrus et } \\
\text { al., 2015; Staykova and Damsgaard, 2015; } \\
\text { Zhong and Nieminen, } 2015\end{array}$ & 8 \\
\hline
\end{tabular}




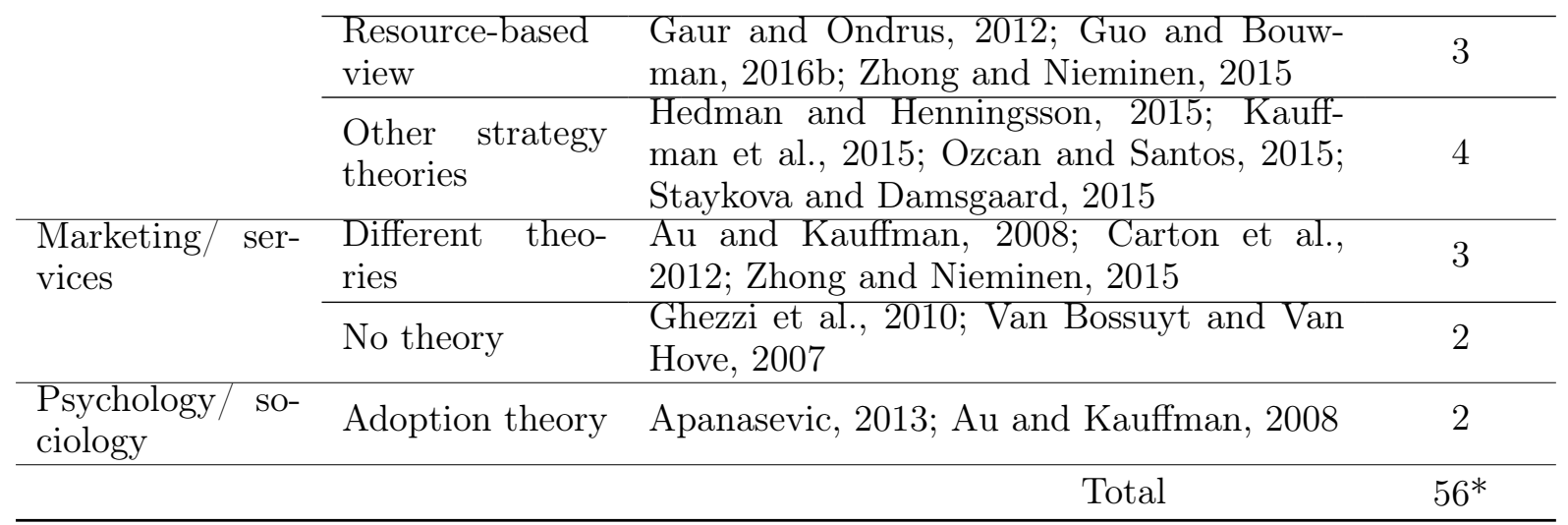

* Some papers were situated in more than one discipline and used more than one theoretical perspective; they were therefore placed in multiple categories. 


\section{Biographies}

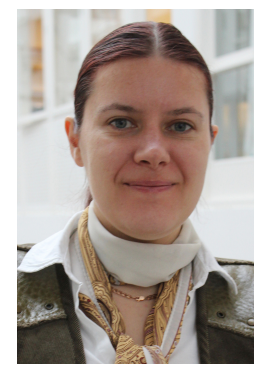

Tatjana Apanasevic. Tatjana Apanasevic received the Bachelor in Business administration and management and Master degree in economic information science from Vilnius University, Vilnius, Lithuania, retrospectively in 1998 and 2000, the M.S. degree in media management from KTH Royal Institute of Technology in 2012, and the PhD degree in information and communication technology from KTH Royal Institute of Technology in 2018. Her research interest includes analysis of economic and business aspects of mobile payments, NFC-based services, and mobile ticketing services. Dr. Apanasevic's awards and honors include a scholarship from Jan Wallanders och Tom Hedelius fund and Tore Browaldhs fund.

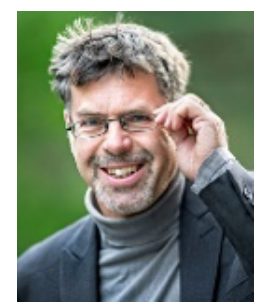

Niklas Arvidsson. Niklas Arvidsson was born in Stockholm, Sweden, 1964. He received the MBA degree in Financial Economics from the Stockholm School of Economics, Sweden, in 1991 and the Ph.D. degree in International Business the Stockholm School of Economics, Sweden, in 1999. From 2000 to 2005, he was Senior Consultant with Service Management Group (SMG) as well as an independent consultant, and from 2005 to 2007 a researcher at the National Institute of Working Life. Since 2007, he has been an Associate Professor at the Royal Institute of Technology in Stockholm. He is the author of three books, many academic articles, and is regularly interviewed in national and international media. His research interests include innovation in the payment system, cashless societies, management and governance of innovation, scenario analysis, sustainable technologies, and digital currencies.

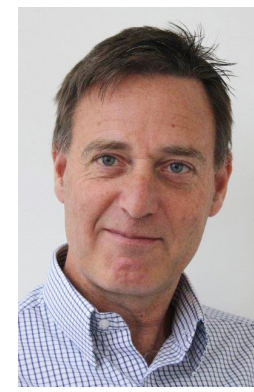

Jan Markendahl. Associate Professor Jan Markendahl, Royal Institute of Technology (KTH), Stockholm. Jan holds a position as Associate Professor in Wireless Infrastructure Deployment and Economics at KTH. After more than 20 years in the industry Jan joined KTH 2003 as research program manager. He has a PhD degree from 2011 in Technoeconomic analysis of wireless networks and services. 2014 Jan got the Docent degree enabling him to be main advisor for $\mathrm{PhD}$ students. So far three $\mathrm{PhD}$ and four Licentiate degrees have been awarded to his Phd students. Jan has managed techno-economic research projects and tasks in EU and national projects. He has made research contributions in the following areas: low cost wireless infrastructure, spectrum valuation, mobile payment and NFC services, IoT and M2M communication services and analysis of business models and ecosystems. Currently he works with business aspects of IoT, smart cities and sharing economy 